\title{
Investigating the quality of modeled aerosol profiles based on combined lidar and sunphotometer data
}

\author{
Nikolaos Siomos ${ }^{1}$, Dimitris S. Balis ${ }^{1}$, Anastasia Poupkou ${ }^{1}$, Natalia Liora ${ }^{1}$, Spyridon Dimopoulos $^{1}$, Dimitris Melas ${ }^{1}$, \\ Eleni Giannakaki $^{2,5}$, Maria Filioglou ${ }^{1,2}$, Sara Basart ${ }^{3}$, and Anatoli Chaikovsky ${ }^{4}$ \\ ${ }^{1}$ Laboratory of Atmospheric Physics, Physics Department, Aristotle University of Thessaloniki, Thessaloniki, Greece \\ ${ }^{2}$ Finnish Meteorological Institute, Atmospheric Research Centre of Eastern Finland, Kuopio, Finland \\ ${ }^{3}$ Earth Sciences Department, Barcelona Supercomputing Center, BSC-CNS, Barcelona, Spain \\ ${ }^{4}$ Institute of Physics, National Academy of Science, Minsk, Belarus \\ ${ }^{5}$ Department of Environmental Physics and Meteorology, Faculty of Physics, University of Athens, Athens, Greece \\ Correspondence to: Nikolaos Siomos (nsiomos@physics.auth.gr)
}

Received: 16 December 2016 - Discussion started: 13 January 2017

Revised: 13 April 2017 - Accepted: 1 May 2017 - Published: 14 June 2017

\begin{abstract}
In this study we present an evaluation of the Comprehensive Air Quality Model with extensions (CAMx) for Thessaloniki using radiometric and lidar data. The aerosol mass concentration profiles of CAMx are compared against the $\mathrm{PM}_{2.5}$ and $\mathrm{PM}_{2.5-10}$ concentration profiles retrieved by the Lidar-Radiometer Inversion Code (LIRIC). The CAMx model and the LIRIC algorithm results were compared in terms of mean mass concentration profiles, center of mass and integrated mass concentration in the boundary layer and the free troposphere. The mean mass concentration comparison resulted in profiles within the same order of magnitude and similar vertical structure for the $\mathrm{PM}_{2.5}$ particles. The mean centers of mass values are also close, with a mean bias of $0.57 \mathrm{~km}$. On the opposite side, there are larger differences for the $\mathrm{PM}_{2.5-10}$ mode, both in the boundary layer and in the free troposphere. In order to grasp the reasons behind the discrepancies, we investigate the effect of aerosol sources that are not properly included in the model's emission inventory and in the boundary conditions such as the wildfires and the desert dust component. The identification of the cases that are affected by wildfires is performed using wind backward trajectories from the Hybrid Single Particle Lagrangian Integrated Trajectory (HYSPLIT) model in conjunction with satellite fire pixel data from MODerate-resolution Imaging Spectroradiometer (MODIS) Terra and Aqua global monthly fire location product MCD14ML. By removing those cases the correlation coefficient improves from 0.69 to 0.87 for the $\mathrm{PM}_{2.5}$ integrated mass in the boundary layer and from 0.72
\end{abstract}

to 0.89 in the free troposphere. The $\mathrm{PM}_{2.5}$ center of mass fractional bias also decreases to $0.38 \mathrm{~km}$. Concerning the analysis of the desert dust component, the simulations from the Dust Regional Atmospheric Model (BSC-DREAM8b) were deployed. When only the Saharan dust cases are taken into account, BSC-DREAM8b generally outperforms CAMx when compared with LIRIC, achieving a correlation of 0.91 and a mean bias of $-29.1 \%$ for the integrated mass in the free troposphere and a correlation of 0.57 for the center of mass. CAMx, on the other hand, underestimates the integrated mass in the free troposphere. Consequently, the accuracy of CAMx is limited concerning the transported Saharan dust cases. We conclude that the performance of CAMx appears to be best for the $\mathrm{PM}_{2.5}$ particles, both in the boundary layer and in the free troposphere. Sources of particles not properly taken into account by the model are confirmed to negatively affect its performance, especially for the $\mathrm{PM}_{2.5-10}$ particles.

\section{Introduction}

There is a wide variety of atmospheric models that are capable of providing vertical profiles of the aerosol mass concentration (e.g., CAMx, BSC-DREAM8b, the LOng Term Ozone Simulation-EURopean Operational Smog (LOTOSEUROS) model, CHIMERE). This is achieved through simulation of the atmospheric motion and the chemical reactions 
that are taking place inside the atmosphere. The most common approach to validating the modeled vertical mass concentration products is to compare with surface and columnar concentration or optical measurements either from groundbased or satellite instruments (e.g., Takemura et al., 2002; Stier et al., 2005; Katragkou et al., 2010; Huneeus et al., 2011; Basart et al., 2012a; Marécal et al., 2015). This approach, however, does not verify the ability of the model to accurately predict the vertical distribution of the aerosol concentration. Observational aerosol profiles comparable with the modeled ones are required for this purpose. Remote sensing techniques such as lidar measurements can provide us with this sort of profile. Since the main lidar products typically involve optical aerosol properties such as the aerosol backscatter and extinction coefficient profiles, it is common to ensure comparability by converting the model's output after applying appropriate techniques. For example, Mona et al. (2014) compare the dust extinction profiles of the BSCDREAM8b model and the respective EARLINET (European Aerosol Research LIdar NETwork) profiles for a 12-year period in Potenza. Meier et al. (2012) use lidar backscatter profiles as one of the tools to evaluate the Consortium for Small-scale Modeling - Multi-Scale Chemistry Aerosol Transport (COSMO-MUSCAT) model for the $\mathrm{PM}_{2.5}$ and $\mathrm{PM}_{10}$ particles. Hodzic et al. (2004) recreate the lidar attenuated backscatter profiles using the output of the CHIMERE model in order to compare the model's $\mathrm{PM}_{10}$ profiles with the lidar measurements.

On the other hand, there are techniques that allow the estimation of the aerosol vertical concentration from remote sensing lidar measurements using a suitable algorithmic inversion method (e.g., Böckmann, 2001; Veselovskii et al., 2002; Raut and Chazette, 2009; Lopatin et al., 2013; Chaikovsky et al., 2016). The advantage of this approach is that the modeled product can be directly validated without the need for conversion. The literature focused on the validation of dust transportation models with observational aerosol concentration profiles is quite old. For example, Binietoglou et al. (2015) have presented a methodology based on LIRIC to evaluate the performance of dust models using data from multiple AERONET (AErosol RObotic NETwork) and EARLINET stations. Granados-Muñoz et al. (2016b) also use the LIRIC algorithm to compare between observational data and a variety of dust models in the framework of the July 2012 CHemistry and AeRosols Mediterranean EXperiments ChArMEx/EMEP campaign. However, there is a lack of studies that focus on the evaluation of both $\mathrm{PM}_{2.5}$ and $\mathrm{PM}_{10}$ concentration profiles simulated by atmospheric models. Royer et al. (2011) compare the simulations of the CHIMERE chemistry transport model for the $\mathrm{PM}_{10}$ particles using lidar $\mathrm{PM}_{10}$ concentration profiles derived with the methodology of Raut and Chazette (2009). In this study we investigate the validity of the aerosol concentration profiles simulated with the Comprehensive Air Quality Model with extensions (CAMxversion5.3) air quality model
(ENVIRON 2010, 2010) for Thessaloniki, Greece $\left(40.5^{\circ} \mathrm{N}\right.$, $22.9^{\circ} \mathrm{E}$ ), using the results of the Lidar-Radiometer Inversion Code (LIRIC). Instead of evaluating the performance of CAMx only for the $\mathrm{PM}_{10}$ particles, we separate the fine and coarse particles by applying the LIRIC technique, and then we convert the fine and coarse concentration profiles of LIRIC to $\mathrm{PM}_{2.5}$ and $\mathrm{PM}_{2.5-10}$ profiles and perform the validation for $\mathrm{PM}_{2.5}$ and $\mathrm{PM}_{2.5-10}$ individually.

CAMx is running operationally to produce a 3-day air quality forecast for Thessaloniki (Zyryanov et al., 2012; Marécal et al., 2015). It provides vertical concentration profiles of a variety of gaseous and aerosol components.

A second model, the BSC-DREAM8b desert dust transportation model (Nickovic et al., 2001; Pérez et al., 2006a, b; Basart et al., 2012b), has also been included in the analysis in order to investigate the performance of CAMx in the case of dust transportation events. This model can provide total dust concentration profiles.

The LIRIC inversion (Chaikovsky et al., 2016), on the other hand, is a technique used to estimate the concentration profiles of the fine and coarse mode aerosol using both sunphotometer and lidar data. Lidar and sunphotometer measurements performed at the Laboratory of Atmospheric Physics of Aristotle University of Thessaloniki, Greece $\left(40.5^{\circ} \mathrm{N}, 22.9^{\circ} \mathrm{E}\right)$, from the period $2013-2015$ were used as input data for the algorithm.

Validating the accuracy of CAMx simulations for Thessaloniki for the period 2013-2015 could prove useful in the aerosol classification procedure of the lidar measurements since individual aerosol components are provided by CAMx. Furthermore, from the modelers' point of view, the comparison could also reveal the need for adjustments in the model's aerosol emissions, boundary conditions and mixing processes.

The paper is organized as follows. In Sect. 2 the two models, CAMx and BSC-DREAM8b, and the LIRIC algorithm are described in detail. The third section is devoted to the methodology of the analysis. This includes the preprocessing of the lidar and the sunphotometer measurements and the characterization of the lidar profiles, the demonstration of the strategy that we applied for the comparison and the application of two example cases. The results of the study are discussed in Sect. 4. Finally, Sect. 5 contains the main conclusions of this study.

\section{Data, algorithm and models}

\subsection{The lidar system of Thessaloniki}

Lidar measurements from the THEssaloniki LIdar SYSstem (THELISYS), which is located at the Laboratory of Atmospheric Physics (LAP) of Aristotle University of Thessaloniki $\left(40.5^{\circ} \mathrm{N}, 22.9^{\circ} \mathrm{E}\right)$ at $50 \mathrm{~m}$ above sea level, during the period 2013-2015 were selected for this study. The setup of 
the system in this period includes two Raman channels at 355 and $532 \mathrm{~nm}$ and three elastic channels at 355, 532 and $1064 \mathrm{~nm}$. The raw lidar signals from the elastic channels at the three aforementioned wavelengths are necessary in order to perform the LIRIC inversion. All signal pre-prepossessing procedures are applied directly in the LIRIC algorithm. The lidar station of Thessaloniki has participated in the European Aerosol Research Lidar Network (EARLINET) (Schneider et al., 2000; Pappalardo et al., 2014) since 2000. More details on the instrument can be found in Amiridis et al. (2005) and (Giannakaki et al., 2010).

\subsection{The CIMEL sunphotometer}

In order to apply the LIRIC inversion, sunphotometer observations are necessary. We used measurements from a CIMEL multiband sun-sky photometer which was installed in Thessaloniki in 2003 as part of the AERONET Global Network. It belongs to the Laboratory of Atmospheric Physics (LAP) and is located at a distance of less than $50 \mathrm{~m}$ from the lidar instrument (see Sect. 2.1) at the same altitude. It automatically performs direct solar irradiance and sky radiance measurements at $340,380,440,500,670,870$, and $1020 \mathrm{~nm}$. The data processing is performed automatically with the AERONET inversion algorithms (Dubovik and King, 2000; Dubovik et al., 2006). The level 2 version 2 inversion data during the period 2013-2015 were used in this study. The instrument and the AERONET infrastructure are described in detail in Holben et al. (1998).

\subsection{The Comprehensive Air quality Model with extensions (CAMx)}

An air quality forecast modeling system was set up in the framework of the EU Monitoring Atmospheric Composition and Climate (MACC) project. It consists of the Weather Research and Forecasting meteorological model (WRF version 3.5.1) described in Skamarock et al. (2008) and the CAMx photochemical model (version 5.3). It is designed to provide the air quality forecast in four nested grids covering Europe (30 km spatial resolution European grid also covering a part of the Sahara), the eastern Mediterranean (10 km spatial resolution grid) and Greek urban centers Thessaloniki and Athens ( $2 \mathrm{~km}$ spatial resolution grids). A nesting technique is applied in order to increase the accuracy in the area of interest, i.e., Thessaloniki. The domains of CAMx are presented in Fig. 1. A single grid point in Thessaloniki is chosen at $\left(40.633^{\circ} \mathrm{N}\right.$, $22.956^{\circ} \mathrm{E}$ ) for the model outputs processed in the present study to coincide with the lidar measurements. The model grids are configured in 17 vertical layers extending up to about $9.5 \mathrm{~km}$ above ground level (a.g.l.). The temporal resolution of CAMx outputs and consequently of the simulated profiles is $1 \mathrm{~h}$.

The aerosol particles are modeled using a static twomode coarse/fine scheme in CAMx for the representation of

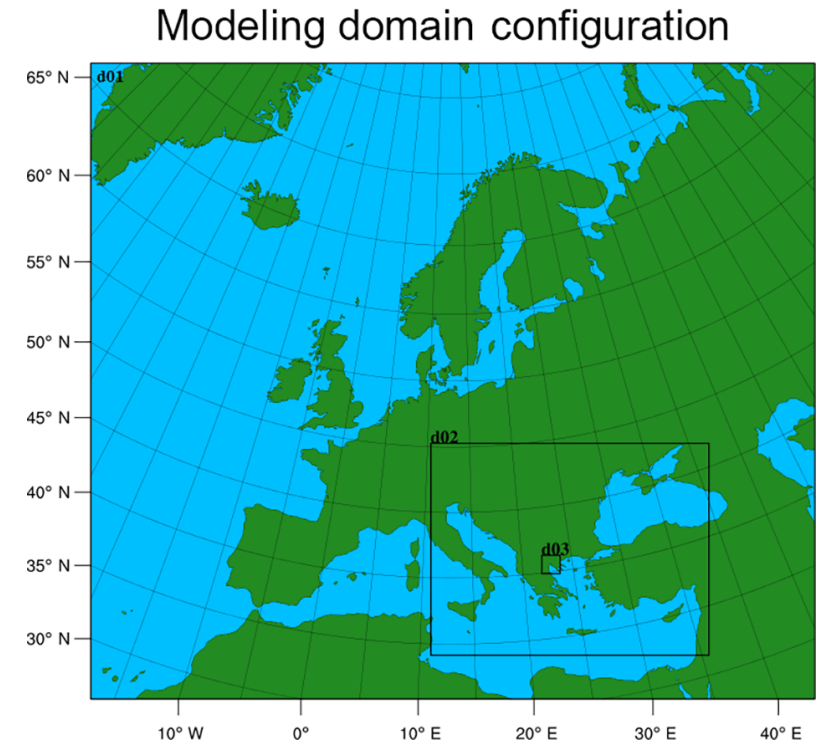

Figure 1. The three domains of CAMx: the European domain (d01), the Balkan domain (d02) and the domain of Thessaloniki (d03). A nesting technique is applied in order to increase the accuracy in the inner domains.

the particle size distribution. Fine particles have a diameter smaller than $2.5 \mu \mathrm{m}$, while coarse particles have a diameter larger than $2.5 \mu \mathrm{m}$ and smaller than $10 \mu \mathrm{m}$. A total of 20 individual aerosol components plus the aerosol water content that is absorbed by the hygroscopic particles are provided by the model (see Table 1). The aerosol aqueous inorganic chemistry is applied according to the RADM-AQ aqueous chemistry algorithm (Chang et al., 1987). The partitioning of the inorganic aerosol constituents between the gas and aerosol phases is performed using the ISORROPIA thermodynamic module (Nenes et al., 1998). The secondary organic aerosol (SOA) formation/partitioning was performed with the use of the SOAP scheme (Strader et al., 1999). SOA are formed by non-methane volatile organic compounds of anthropogenic and natural origin. Details on the CAMx aerosol components such as the hygroscopicity and the mode type can be found in Table 1.

CAMx is applied with the use of gaseous and particulate anthropogenic and natural emissions. Particulate matter emissions from natural sources (windblown dust and sea salt aerosol) and biogenic volatile organic compounds from vegetation are estimated using the Natural Emission MOdel NEMO version 1 (Markakis et al., 2009; Poupkou et al., 2010; Markakis, 2010) driven by the WRF meteorology. The Model for the Spatial and Temporal Distribution of Emissions (MOSESS) (Markakis et al., 2013) was applied for the calculation of spatially and temporally disaggregated and chemically speciated anthropogenic emission data of the following pollutants: $\mathrm{CO}, \mathrm{NO}_{x}, \mathrm{SO}_{2}, \mathrm{NH}_{3}, \mathrm{NMVOC}, \mathrm{PM}_{10}$ and $\mathrm{PM}_{2.5}$. The anthropogenic emissions were estimated using 
Table 1. CAMx aerosol component synopsis. Fine Other Primary mainly consisted of the $\mathrm{PM}_{2.5}$ aerosols that are treated as inert by the model. It also contains a small part of the $\mathrm{PM}_{2.5}$ sea salt that cannot be treated as particulate chloride or as sodium. The Coarse Other Primary component includes all the $\mathrm{PM}_{2.5-10}$ aerosols that are not crustal (nitrate, sulfate, ammoniac, black carbon and primary organic aerosols) as well as the $\mathrm{PM}_{2.5-10}$ sea salt and all the other particles that are considered inert by the model.

\begin{tabular}{llll}
\hline Components & Hygroscopic & Mode & Category \\
\hline Particulate nitrate $(\mathrm{NO})$ & yes & $\mathrm{PM}_{2.5}$ & water soluble \\
Sulfate $\left(\mathrm{SO}_{4}\right)$ & yes & $\mathrm{PM}_{2.5}$ & water soluble \\
Particulate ammonium $\left(\mathrm{NH}_{4}\right)$ & yes & $\mathrm{PM}_{2.5}$ & water soluble \\
Aerosol water content $\left(\mathrm{H}_{2} \mathrm{O}\right)$ & - & $\mathrm{PM}_{2.5}$ & water \\
Anthropogenic SOA* & no & $\mathrm{PM}_{2.5}$ & organic insoluble \\
Biogenic SOA* & no & $\mathrm{PM}_{2.5}$ & organic insoluble \\
Polymerized anthropogenic SOA* & no & $\mathrm{PM}_{2.5}$ & organic insoluble \\
Polymerized biogenic SOA* & no & $\mathrm{PM}_{2.5}$ & organic insoluble \\
Sodium $(\mathrm{Na})$ & yes & $\mathrm{PM}_{2.5}$ & sea salt $\mathrm{PM}_{2.5}$ \\
Particulate chloride $(\mathrm{Cl})$ & yes & $\mathrm{PM}_{2.5}$ & sea salt $\mathrm{PM}_{2.5}$ \\
Primary organic aerosol & no & $\mathrm{PM}_{2.5}$ & organic insoluble \\
Primary elemental carbon $(\mathrm{C})$ & no & $\mathrm{PM}_{2.5}$ & soot \\
Fine Other Primary & no & $\mathrm{PM}_{2.5}$ & other $\mathrm{PM}_{2.5}$ \\
Fine Crustal & no & $\mathrm{PM}_{2.5}$ & soil $\mathrm{PM}_{2.5}$ \\
Coarse Other Primary & no & $\mathrm{PM}_{2.5}-10$ & other $\mathrm{PM}_{2.5-10}$ \\
Coarse Crustal & no & $\mathrm{PM}_{2.5}-10$ & soil $\mathrm{PM}_{2.5-10}$ \\
\hline
\end{tabular}

* SOA: secondary organic aerosol.

either activity data with methodologies and emission factors of the EMEP/CORINAIR - CORe INventory AIR emission inventory guidebook (EEA, 2006) or the emission database of The Netherlands Organization (TNO) for the reference year 2007 (Kuenen et al., 2011). Anthropogenic emissions for the following sources are accounted for: energy production, central heating, industry, transportation, waste treatment and disposal, agricultural activities (i.e., biomass burning, fertilization), extraction and distribution of fossil fuels. It is important to mention that particle emissions due to dust resuspension from agricultural activities and road traffic as well as the wildfire emissions are not currently included in CAMx simulations. Saharan dust emissions are taken into account only indirectly in the CAMx chemical boundary conditions provided by the global forecast modeling systems Integrated Forecasting System (IFS-MOZART) until October 2014 and C-IFS afterwards (Flemming et al., 2009; Morcrette et al., 2009; Stein et al., 2012) in the framework of the MACC project. The model has been evaluated during the MACC-II project (Marécal et al., 2015).

\subsection{The BSC-DREAM8b model}

The transported desert dust particles and the forest fire particles are common categories of aerosol components in Thessaloniki (Amiridis et al., 2005; Basart et al., 2009; Giannakaki et al., 2010). As has already been stated, the setup of CAMx in Thessaloniki includes the desert dust component only from the global boundary conditions and does not include wildfire emissions at all. Biases in those two aerosol components are expected to affect both aerosol modes since the desert dust particles are coarse dominant (Shettle and Fenn, 1979; d'Almeida, 1987) and the biomass burning particles are fine dominant (Tesche et al., 2009; Groß et al., 2013).

The desert dust component can be further analyzed by comparing LIRIC with a dust specialized model. The BSCDREAM8b dust transportation model (Pérez et al., 2006a, b; Nickovic et al., 2012; Basart et al., 2012b) was chosen for the comparison. BSC-DREAM8b is managed by the Barcelona Supercomputer Center (BSC) and has provided operational forecasts since May 2009, and is also participating in the northern Africa-Middle East-Europe (NA-ME-E) node of the World Meteorological Organization (WMO) Sand and Dust Storm Advisory and Assessment System (SDS-WAS) project. The BSC-DREAM8b model is embedded in the Eta/NCEP atmospheric model and solves the mass balance equation for dust, taking into account the different processes of the dust cycle (i.e., dust emission, transport and deposition). The updated version of the model includes eight particle size bins $(0.1-10 \mu \mathrm{m}$ radius range) and dust-radiative feedback.

The BSC-DREAM8b model has been evaluated for longer periods over northern Africa and Europe (e.g., JiménezGuerrero et al., 2008; Pay et al., 2010, 2012; Basart et al., 2012b, a; Gama et al., 2015) and against experimental campaigns in source regions during the SAharan Mineral dUst experiMent - SAMUM-1 (Haustein et al., 2009) and the Bodélé Dust Experiments (BoDEx, Todd et al., 2008). Furthermore, daily evaluation of BSC-DREAM8b with near-real-time observations is conducted at BSC. Currently, the daily operational model evaluation includes satel- 
lites (MODIS and MSG - Meteosat Second Generation) and AERONET sun photometers. Some comparisons between lidar and forecast model profiles were performed in terms of aerosol vertical distribution for specific Saharan dust events in the Mediterranean Basin (e.g., Balis et al., 2004; Pérez et al., 2006a; Amiridis et al., 2009; Mona et al., 2012; Gobbi et al., 2013; Amiridis et al., 2013; Mona et al., 2014). In addition, Binietoglou et al. (2015) include BSC-DREAM8b as one of the models that participate in their analysis, validating its performance against LIRIC retrievals at 10 EARLINET/AERONET stations.

The present analysis includes the daily runs of BSCDREAM8b. The initial state of dust concentration in the model was defined by the $24 \mathrm{~h}$ forecast from the previous-day model run. The Final Analyses of the National Centers of Environment Prediction (NCEP/FNL; at $1^{\circ} \times 1^{\circ}$ ) at 00:00 UTC were used every $24 \mathrm{~h}$ as initial conditions and boundary conditions at intervals of $6 \mathrm{~h}$. The model configuration used for the present study includes 24 Eta vertical layers extending up to approximately $15 \mathrm{~km}$ in the vertical. The resolution is set to $0.3^{\circ}$ in the horizontal. The temporal resolution of the simulations is $3 \mathrm{~h}$. The domain of simulation covers northern Africa, the Middle East and Europe. It is worth mentioning that re-suspended wind-blown dust and the considered desert dust sources are limited to northern Africa and the Middle East $\left(<35^{\circ} \mathrm{N}\right)$ in the BSC-DREAM8b model.

\subsection{The LIdar-Radiometer Inversion Code (LIRIC)}

The LIRIC algorithm utilizes both radiometric data that have been processed by the AERONET inversion algorithm (Dubovik and King, 2000; Dubovik et al., 2006) and also raw lidar signals at three wavelengths $(355,532$ and $1064 \mathrm{~nm})$ in order to estimate the aerosol concentration profiles for the fine and coarse particles. The radiometric data used as input include the aerosol size distribution, the aerosol volume concentration in the two modes (fine and coarse), the aerosol optical depth (AOD) and the single scattering albedo (SSA) of each mode, the complex refractive index in each wavelength, the sphericity and the aerosol phase function. The minimum of the aerosol size distribution in the $0.194-0.576 \mu \mathrm{m}$ radius range is used as the size boundary that separates the fine and coarse modes. In case the particle depolarization ratio is also provided, it is possible for the algorithm to further separate the spherical coarse particles from the non-spherical ones. Nevertheless, only the fine and coarse mode retrievals are taking part in this study due to the lack of depolarization ratio profiles.

The algorithm main products are the vertical volume concentration profiles in the two modes. In brief, the algorithm searches for the profile per mode that gives the best agreement between the actual data and the reconstructed data from the algorithm, also demanding a certain degree of vertical smoothness in the final product. The reconstructed data include the aerosol backscatter profiles in the three lidar wave- lengths and the columnar volume concentration values per mode. A detailed description of LIRIC can be found in Chaikovsky et al. (2016).

The effects of multiple user-defined uncertainties, such as the upper and lower limit heights of the profile and the algorithm's regularization parameters, on the final result have been studied by Granados-Muñoz et al. (2014) and Filioglou et al. (2017) for selective case studies in Granada and Thessaloniki, respectively. They agree that the parameter that produces the biggest uncertainties is the lower limit height of the profile. Furthermore, the LIRIC retrievals have already been evaluated for volcanic and desert dust particles by Wagner et al. (2013), showing that the inversion can be accurate for two quite different types of aerosol. The aerosol extinction products of LIRIC have also been compared against the respective products from the Generalized Aerosol Retrieval from Radiometer and Lidar Combined data (GARRLiC) algorithm and against the retrievals from Raman lidar measurements (Bovchaliuk et al., 2016). Finally, LIRIC has also been validated against in situ aircraft measurements (e.g., Granados-Muñoz et al., 2016a; Kokkalis et al., 2017). Granados-Muñoz et al. (2016a) compared the LIRIC retrievals with airborne in situ measurements and found a promising agreement with the differences between the two staying within the expected uncertainties. Kokkalis et al. (2017) analyzed a biomass burning case. Their comparison between the LIRIC retrievals and the aircraft measurements resulted in a good performance of the algorithm for the fine particles. As a result it can be used as an independent reliable tool for the validation of CAMx.

\section{Methodology}

The analysis is divided into two parts. Section 3.1 corresponds to the pre-processing of the algorithm's and the model's estimates in order to calculate comparable final products. The aerosol type identification of the lidar profiles is also described there. The methodology of the comparison is included in Sect. 3.2. Two sample cases are presented in Sect. 3.3, aiming to give an example of the products that the algorithm and the models can provide and also to demonstrate typical problems that occur in the analysis.

\subsection{Pre-processing}

In the first part of this section, the pre-processing procedure of the lidar measurements is described. In the second part, we present the methodology that was applied in order to characterize the lidar profiles.

\subsubsection{Lidar pre-processing}

The LIRIC algorithm requires both the raw lidar signal resulting from the atmospheric elastic backscattering in 355, 532 and $1064 \mathrm{~nm}$ and the Version 2 Inversions from 
AERONET. Lidar measurements performed in Thessaloniki during the period 2013-2015 were used for this purpose. Before September 2012, the setup of the lidar system in Thessaloniki was lacking a $1064 \mathrm{~nm}$ channel that is necessary for the LIRIC inversion. A manual cloud screening process was also applied in order to remove all the cloud affected lidar measurements since LIRIC is not designed for cloud layers. In addition, only daytime measurements were used since the sunphotometer only operates during daytime. It is important to mention that both instruments are located close to one another and at the same altitude above sea level (see Sect. 2.1 and 2.2).

The sunphotometer data are processed by the AERONET algorithms in order to calculate the necessary aerosol properties which are required as input for the algorithm. In our analysis, the closest AERONET inversion to the central time of the lidar measurement was selected for the LIRIC retrievals. Cases with an absolute time difference that exceeded $3 \mathrm{~h}$ between the sunphotometer measurement time and the central time of the lidar measurement were excluded. The lidar signal pre-processing is performed directly in LIRIC (Chaikovsky et al., 2016) and includes the averaging, smoothing, background correction and range correction procedures as well as the normalization of the lidar signals and also the selection of the lower and upper height boundaries in the signal where the LIRIC inversion is going to be performed. All the signals are adjusted to a common vertical resolution with a constant step of $15 \mathrm{~m}$. A lower height boundary has to be determined due to the overlap function of the lidar system. Operationally, we apply the method of Wandinger and Ansmann (2002) for the calculation of the overlap function and the full overlap height. In the current dataset the full overlap height was calculated at $900 \mathrm{~m}$. The correction however cannot be trusted down to the ground (Wandinger and Ansmann, 2002). In this study, we apply the correction down to $600 \mathrm{~m}$, where the overlap function is still above $90 \%$, and use this height as the lower boundary of the LIRIC inversion. Below this height the lidar signals are considered constant during the LIRIC inversion. The concentration retrievals are also kept constant below $600 \mathrm{~m}$. As was mentioned in Sect. 2.3, this can produce uncertainties since the radiometric data correspond to the whole atmospheric column and most of the aerosol is usually located in the boundary layer, close to the ground. According to Granados-Muñoz et al. (2014) the selection of the lower limit is the main source of error. They estimate the maximum uncertainty due to such intrinsic errors at $33 \%$ and the overall profile error to stay below $15 \%$ most of the time. They also mention that use of an overlap correction could reduce this uncertainty.

The upper boundary depends on the maximum height where aerosol exists in a significant quantity, that is, a region where the lidar signal from the aerosol backscattering can no longer be separated from the noise. This height can vary, depending on the atmospheric conditions. The output data of the algorithm include vertical volume concentration profiles of the fine and coarse mode particles in ppbv. By adding the concentration in the two modes one can calculate the total aerosol concentration.

The vertical resolution of the LIRIC products and the model products is different, so it was necessary to upscale LIRIC to the resolution of each model. This can affect the vertical structure of the profiles for individual cases, but in a statistical analysis those effects will be smoothed (Binietoglou et al., 2015). The temporal resolution of CAMx forecasts is $1 \mathrm{~h}$, while the temporal resolution of BSCDREAM $8 \mathrm{~b}$ forecasts is $3 \mathrm{~h}$. Each of the retrieval algorithm's profiles was matched to the models' profile closest to the central lidar measurement. Since LIRIC-derived concentration values are in ppbv units while both models' profiles are in $\mu \mathrm{g} \mathrm{m}^{-3}$ units, it was necessary to apply a unit conversion that also requires the aerosol density. Despite the aerosol component densities of CAMx being known, we preferred to convert ppbv to $\mu \mathrm{g} \mathrm{m}^{-3}$ (Eq. 1) since $\mu \mathrm{g} \mathrm{m}^{-3}$ is more widely used as a concentration unit.

$c_{\mu \mathrm{g} \mathrm{m}}^{-3}=10^{3} \cdot c_{\mathrm{ppbv}} \cdot \rho_{\mathrm{g} \mathrm{cm}^{-3}}$,

where $\rho$ is the mean aerosol density. Typical density values of 1.5 and $2.6 \mathrm{~g} \mathrm{~cm}^{-3}$ for the fine and coarse mode particles were used, respectively (Bukowiecki et al., 2011; Schumann et al., 2011; Kokkalis et al., 2013).

Another hindrance in the analysis is that the fine and coarse modes of LIRIC are not directly comparable with the $\mathrm{PM}_{2.5}$ and $\mathrm{PM}_{2.5-10}$ modes of CAMx. The $\mathrm{PM}_{2.5}$ particles should include all the fine particles and a small part of the coarse particles that changes depending on the case. Additionally, the size distribution of the sunphotometer usually surpasses the $\mathrm{PM}_{10}$ diameter limit. Fortunately, it is possible to convert the fine and coarse modes of LIRIC to $\mathrm{PM}_{2.5}$ and $\mathrm{PM}_{2.5-10}$ particles. In the LIRIC inversion, the normalized volume size distribution of each mode is derived by separating the columnar size distribution of the sunphotometer in the two modes. The normalized distribution of each mode remains constant with height. Taking that into account, the fractions of the sunphotometer's coarse mode that belong in the $\mathrm{PM}_{2.5}$ region and the region outside the $\mathrm{PM}_{10}$ particles can be calculated from the sunphotometer's volume size distribution. Then, the fine and coarse concentration profiles of each LIRIC case can be converted to $\mathrm{PM}_{2.5}$ and $\mathrm{PM}_{2.5-10}$ profiles using Eqs. (2) and (3).

$$
\begin{gathered}
c_{\mathrm{PM}_{2.5}}(z)=c_{\text {fine }}(z)+c_{\text {coarse }}(z) \cdot \frac{\int_{r_{\mathrm{f}-\mathrm{c}}}^{r_{\mathrm{PM}}} \frac{\mathrm{d} V}{\mathrm{~d} r} \cdot \mathrm{d} r}{\int_{r_{\mathrm{f}-\mathrm{c}}}^{r_{\mathrm{c}}} \frac{\mathrm{d} V}{\mathrm{~d} r} \cdot \mathrm{d} r}, \\
c_{\mathrm{PM}_{2.5-10}}(z)=c_{\text {coarse }}(z)-c_{\text {coarse }}(z) \\
\left.\int_{r_{\mathrm{PM}_{\mathrm{f}} .5} \frac{\mathrm{d} V}{\mathrm{~d} r} \cdot \mathrm{d} r+\int_{r_{\mathrm{PM}_{10}}}^{r_{\mathrm{c}}} \frac{\mathrm{d} V}{\mathrm{~d} r} \cdot d r}^{r_{r_{\mathrm{f}-\mathrm{c}}} \frac{\mathrm{d} V}{\mathrm{~d} r} \cdot \mathrm{d} r}\right),
\end{gathered}
$$

where $c_{\text {fine }}, c_{\text {coarse }}, c_{\mathrm{PM}_{2.5}}$, and $c_{\mathrm{PM}_{2.5-10}}$ are the concentration profiles of LIRIC before and after the conversion and $\frac{\mathrm{d} V}{\mathrm{~d} r}$ is 
the aerosol volume size distribution of the sunphotometer as a function of the aerosol radius. The radii $r_{\mathrm{c}}, r_{\mathrm{f}-\mathrm{c}}, r_{\mathrm{PM}_{2.5}}$, and $r_{\mathrm{PM}_{10}}$ are in $\mu m$ units and correspond to the upper limit of the sunphotometer size distribution, the separator radius between the fine and coarse modes of the sunphotometer (see Sect. 2.3), which is different for each dataset case, and the $\mathrm{PM}_{2.5}$ and $\mathrm{PM}_{10}$ separator radii, respectively.

\subsubsection{Characterization of the lidar profiles}

It was mentioned in Sect. 2.3 that the emission inventory of CAMx lacks the biomass burning aerosol emissions from wildfires. Additionally, the desert dust emissions are taken into account only indirectly in the CAMx chemical boundary conditions (Sect. 2.3). In order to examine the effect of those cases on the comparison, we group the cases into four categories. The first one is the total of the cases that will be referred to as "all". The second one contains the cases identified as biomass burning wildfire aerosol and will be referred to as "fires" from now on. The aerosol characterization is performed using a combination of model simulations and satellite data. It is described in the next paragraph. When the category "fires" is screened from the category "all", the category "non fires" is formed. It contains the continental and desert dust cases. Finally, the desert dust cases are also isolated and are included in the category "dust".

The backward trajectories from HYSPLIT in conjunction with fire pixel data from the MODIS Terra and Aqua Global Monthly Fire Location Product (MCD14ML) are used to identify the fire cases. The dust cases characterization also utilizes the HYSPLIT trajectories in combination with the BSC-DREAM8b profiles. A pair of 6-day back-trajectories, one arriving in the boundary layer region and another in the free troposphere, were used. The technique that was utilized in order to estimate the boundary layer height per case is described in Sect. 3.2. A high fire spot density in a region where the air masses are passing near the ground is applied as a criterion for the wildfire case identification.

The trajectories for the continental, desert dust and biomass burning cases are presented in Fig. 2 with blue (a and $b$ ), orange (c and d) and black color (e and f), respectively. The left column contains the air masses that arrive in the boundary layer, typically around $1 \mathrm{~km}$, while the right column contains the ones that arrive in the free troposphere, usually ranging between 3 and $4 \mathrm{~km}$. Each trajectory is accompanied by the corresponding accumulated 6-day fire pixels.

\subsection{Comparison strategy}

The first part of the evaluation of CAMx is based on the comparison of the aerosol concentration with the LIRIC estimates for the "all" category (Sect. 4.1). The effect of the wildfire cases on the results is also examined in this section. In the second part, the accuracy of CAMx in events of transported Saharan dust is investigated (Sect. 4.2).

The concentration profiles of all the $\mathrm{PM}_{2.5}$ aerosol components (Table 1) are summed to create the $\mathrm{PM}_{2.5}$ concentration profile of CAMx. The same applies to the $\mathrm{PM}_{2.5-10}$ aerosol components of Table 1 . The water content is included in the $\mathrm{PM}_{2.5}$ group since all the hygroscopic particles are in the same group.

A total of 22 cases take part in the comparison. We preferred a statistical approach in the analysis rather than comparing each case individually since the size of the dataset permits it. The mean profiles of the two models and LIRIC are calculated across the vertical range. The center of mass is also calculated for each case and each mode. It provides additional information on the height where the majority of the particles are located.

The planetary boundary layer (PBL) marks the top of the layer where the atmosphere is well mixed and the local aerosol component is also expected to be significant. On the other hand, the free troposphere (FT) above is related to much less mixing, and a stronger transported aerosol component is expected. Consequently, a comparison between CAMx and LIRIC in the boundary layer and in the free troposphere would be useful in order to investigate the accuracy of the model in these quite different atmospheric regions. Thus, we calculate the $\mathrm{PM}_{2.5}$ and $\mathrm{PM}_{2.5-10}$ integrated mass in the boundary layer and in the free troposphere for each case.

There are multiple techniques in order to estimate the boundary layer from lidar measurements (e.g., Flamant et al., 1997; Menut et al., 1999; Brooks, 2003; Tomasi and Perrone, 2006; Bravo-Aranda et al., 2016). Baars et al. (2008) apply a wavelet covariance transform to the lidar range-corrected signal in order to translate signal layers to maxima and minima of the wavelet covariance transform (WCT). Here we apply the transform to the total concentration derived by LIRIC. However, this is not enough to automatically identify the PBL since the boundaries of multiple layers will be retrieved. Identification criteria are necessary for the selection of the PBL height. The top of the layer between $600 \mathrm{~m}$ and $2.5 \mathrm{~km}$ with the minimum value in the transformed signal is chosen as the boundary layer height. The upper limit is necessary in order to avoid identifying the top of sharp elevated layers as the PBL. According to Georgoulias et al. (2009) the upper limit of $2.5 \mathrm{~km}$ is realistic for Thessaloniki. Baars et al. (2008) presented a case where an elevated dust layer complicated the PBL height retrieval with the WCT method. The wavelet transform is applied to the LIRIC concentration profiles before the upscaling of the resolution.

To perform the integration below and above the PBL, lower and upper boundaries are required. The LIRIC inversion requires a height where the aerosol content is not significant. This height is usually different for each case and typically ranges between 3 and $9 \mathrm{~km}$. On the other hand, CAMx always provides values up to $9.5 \mathrm{~km}$, while BSC-DREAM8b provides values up to $15 \mathrm{~km}$. We used the ground level as 


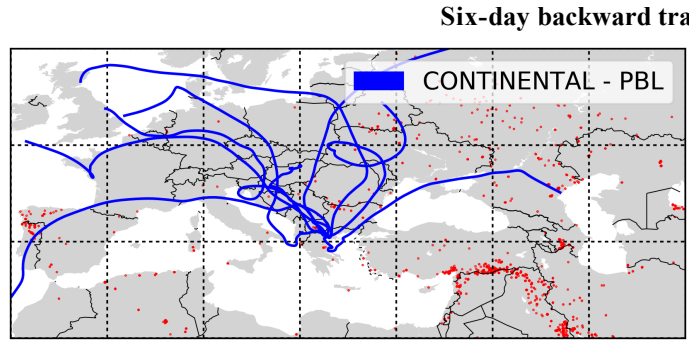

(a)

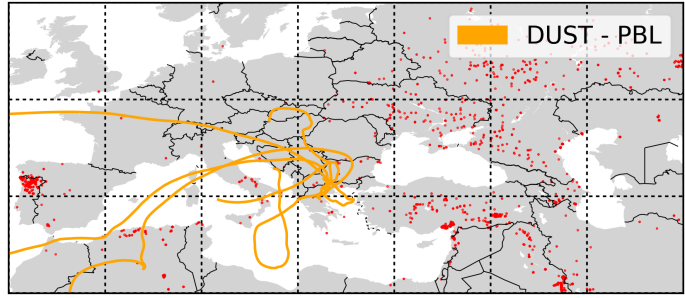

(c)

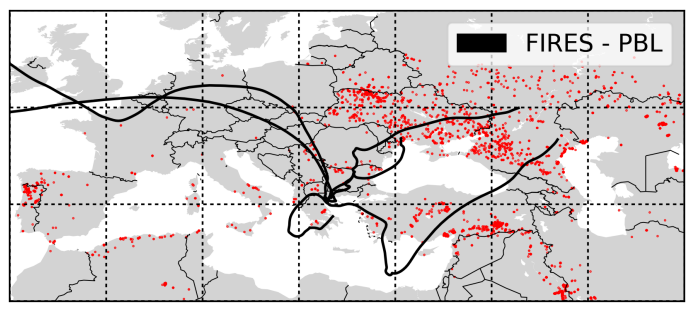

(e)

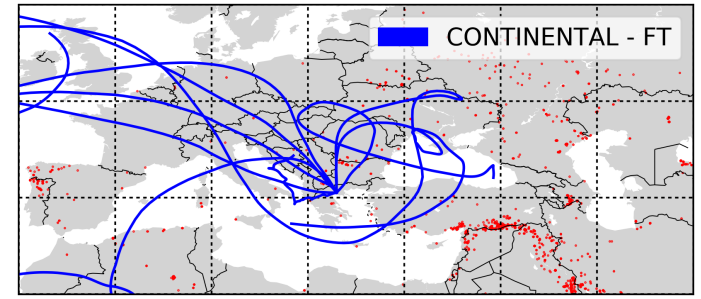

(b)

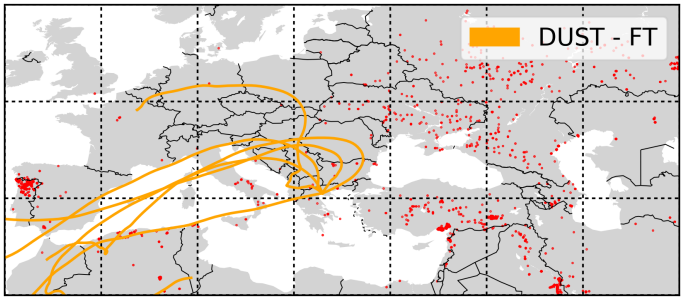

(d)

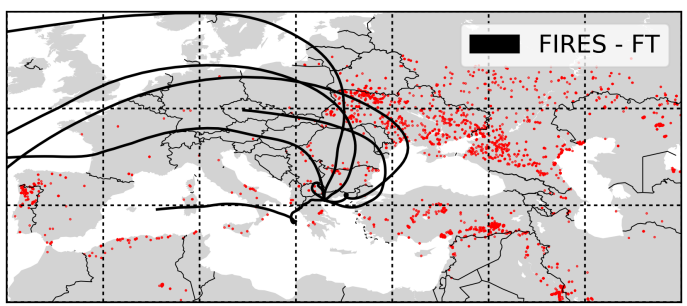

(f)

Figure 2. HYSPLIT 6-day backward trajectories and MODIS fire pixels for the continental (a, b), desert dust (c, d) and biomass burning (e, f) cases in the period 2013-2015. The left column includes trajectories that arrive in the boundary layer, while the right column includes trajectories arriving in the free troposphere.

the common lower boundary and the upper limit of CAMx $(9.5 \mathrm{~km})$ as the common upper boundary. Since LIRIC profiles usually end below this upper limit, the last value of each profile is considered constant up to $9.5 \mathrm{~km}$.

Metrics for the center of mass and the integrated mass in the boundary layer and in the free troposphere are also calculated. This includes the mean values and the standard deviations for the algorithm and the model, the mean bias error, the mean fractional error, the root mean square error (RMSE), the correlation coefficient and the least squares fit slope and axis intersect values. The equations for some of the metrics can be found in Table 2 .

In order to demonstrate how the comparison strategy was applied, we present two distinct cases which include the aerosol typing procedure, the concentration profile comparison and the optical products that can be derived by the LIRIC algorithm.

\subsection{Example cases}

The products of LIRIC, CAMx, BSC-DREAM8b and HYSPLIT for two case studies are presented here.
Table 2. Common metrics equations. The model data are defined as $M$ and the lidar observational data as $O$. The $z$ and $c$ symbols correspond to the height and the concentration, respectively.

\begin{tabular}{ll}
\hline Metric & Equation \\
\hline Center of mass & $\frac{\int z \cdot c \cdot d z}{\int c \cdot d z}$ \\
\hline Mean bias & $\frac{1}{N} \sum_{i=1}^{N}\left(M_{i}-O_{i}\right)$ \\
\hline Mean fractional bias $(\%)$ & $\frac{200}{N} \sum_{i=1}^{N} \frac{\left(M_{i}-O_{i}\right)}{\left(M_{i}+O_{i}\right)}$ \\
\hline RMSE & {$\left[\frac{1}{N} \sum_{i=1}^{N}\left(M_{i}-O_{i}\right)^{2}\right]^{\frac{1}{2}}$} \\
\hline
\end{tabular}

The main products of LIRIC are the $\mathrm{PM}_{2.5}$ and $\mathrm{PM}_{2.5-10}$ concentration profiles. Additionally, the aerosol extinction and backscattering efficiencies per mode and per wavelength $(355,532,1064 \mathrm{~nm})$ are also derived from the aerosol optical thickness $E_{\mathrm{f}}$ and $E_{\mathrm{c}}$ and the columnar concentration $C_{\mathrm{f}}$ 
and $C_{\mathrm{c}}$ in the fine and coarse modes, respectively. The calculation of the extinction efficiencies is presented in Eqs. (4) and (5). The backscattering efficiencies are produced from the extinction efficiencies using the single scattering albedo and the phase function at $180^{\circ}$. This procedure is described in (Chaikovsky et al., 2016).

$$
\begin{aligned}
Q_{\text {ext }, \mathrm{f}}(\lambda) & =\frac{E_{\mathrm{f}}(\lambda)}{C_{\mathrm{f}}(\lambda)} \\
Q_{\mathrm{ext}, \mathrm{c}}(\lambda) & =\frac{E_{\mathrm{c}}(\lambda)}{C_{\mathrm{c}}(\lambda)}
\end{aligned}
$$

The total extinction and backscatter coefficient profiles, with symbols $a$ and $b$, respectively, for the three wavelengths are calculated using Eqs. (6) and (7), where $Q_{\text {ext }}$ is the extinction efficiency and $Q_{\mathrm{bsc}}$ is the backscattering efficiency calculated by LIRIC. The concentrations for the fine and coarse modes are marked as $c_{\mathrm{f}}$ and $c_{\mathrm{c}}$, respectively.

$$
\begin{aligned}
& a(\lambda, z)=Q_{\mathrm{ext}, \mathrm{f}}(\lambda) \cdot c_{\mathrm{f}}(z)+Q_{\mathrm{ext}, \mathrm{c}}(\lambda) \cdot c_{\mathrm{c}}(z) \\
& b(\lambda, z)=Q_{\mathrm{bsc}, \mathrm{f}}(\lambda) \cdot c_{\mathrm{f}}(z)+Q_{\mathrm{bsc}, \mathrm{c}}(\lambda) \cdot c_{\mathrm{c}}(z)
\end{aligned}
$$

Then, from the LIRIC estimated extinction and backscatter profiles, the lidar ratio and the Angstrom exponent can also be calculated. Furthermore, as was mentioned in Sect. 3.1, the concentration values below $600 \mathrm{~m}$ are kept constant in the LIRIC inversion, and this also applies to the optical products.

A typical continental case on 13 January 2014 and a typical dust case on 27 August 2013 were selected in order to demonstrate the comparison results for two quite different typical aerosol types. The former is demonstrated on the left of Fig. 3 and the latter in the right column.

The trajectories indicate a continental case on 13 January 2014. They are presented in Fig. 3a. Additionally there could be some mixing with marine particles from the Adriatic Sea. The air mass arriving in the free troposphere should be clean according to HYSPLIT since the trajectory is elevated, always above $3 \mathrm{~km}$. The concentration profiles of LIRIC and CAMx are presented in Fig. $3 \mathrm{c}$ and d. According to LIRIC the $\mathrm{PM}_{2.5}$ particles are dominant below $1 \mathrm{~km}$. Above that height there is a $\mathrm{PM}_{2.5-10}$ dominant layer which could be the result of mixing with marine aerosol. The $\mathrm{PM}_{2.5}$ aerosol concentration profile of CAMx seems in good agreement with LIRIC in the near range, below $2 \mathrm{~km}$. On the other hand, CAMx and LIRIC are not in very good agreement for the $\mathrm{PM}_{2.5-10}$ particles.

The four optical products are also presented. The upper part of the Fig. 3g panel contains the aerosol backscatter and extinction coefficient profiles and the lower part the lidar ratio and the extinction Angstrom exponent profiles. The lidar ratio values are around $70 \mathrm{sr}^{-1}$ at $355 \mathrm{~nm}$ and $65 \mathrm{sr}^{-1}$ at $532 \mathrm{~nm}$ below $1 \mathrm{~km}$. The Angstrom values are near 1.6 for the 355-532 nm exponent and at 2.1 for the 532-1064 nm exponent. Giannakaki et al. (2010) report a mean lidar ratio at $355 \mathrm{~nm}$ of $56 \pm 23 \mathrm{sr}^{-1}$ and a backscatter-related Angstrom exponent at $355-532 \mathrm{~nm}$ of $1.4 \pm 1.0$ for the continental polluted aerosol class in Thessaloniki. Between 1 and $2 \mathrm{~km}$ the lidar ratio at $355 \mathrm{~nm}$ drops to $55 \mathrm{sr}^{-1}$ and the lidar ratio at $532 \mathrm{~nm}$ to $45 \mathrm{sr}^{-1}$. The Angstrom exponent in both regions drops near 1.3. According to Giannakaki et al. (2010) those values are still within the acceptable range of the continental polluted class.

As far as the second case is concerned, the trajectories indicate an event of transported Saharan dust in the FT (Fig. 3b). The air masses that arrive in the PBL seem to contain marine aerosol from the Mediterranean, probably mixed with emissions from local urban sources. A strong $\mathrm{PM}_{2.5-10}$ mode can be observed in Fig. 3e both for the layer below $1.5 \mathrm{~km}$ and the layer above. Despite CAMx predicting a promising $\mathrm{PM}_{2.5}$ mode (Fig. 3e), it is not in good agreement for the $\mathrm{PM}_{2.5-10}$ particles (not shown), and this is the reason why the BSC-DREAM8b concentration profile is presented here instead. This model describes the dust layer between 2 and $5 \mathrm{~km}$ much better. This issue is discussed further in Sect. 4.2.

As far as the optical products are concerned, the lidar ratio at 355 and $532 \mathrm{~nm}$ values ranges between 40 and $50 \mathrm{sr}^{-1}$ for all the profiles, while the Angstrom exponent ranges between 1.0 and 1.5 for both spectral regions (Fig. 3h). Giannakaki et al. (2010) calculate a lidar ratio at $355 \mathrm{~nm}$ of $52 \pm 18 \mathrm{sr}^{-1}$ and a backscatter-related Angstrom exponent at $355-532 \mathrm{~nm}$ of $1.5 \pm 1.0$ for the Saharan dust aerosol class at Thessaloniki, which seems compatible with this case. In the next section the statistical analysis is presented and the results are discussed.

\section{Discussion}

An ensemble of 22 measurements that fulfill the criteria described in Sect. 3.2 took part in this comparison. These cases constitute the category "all". In the first part of this section (Sect. 4.1) the comparison between LIRIC and CAMx is presented. In the second part (Sect. 4.2) the accuracy of CAMx in the case of Saharan dust events is investigated using the simulations of BSC-DREAM8b.

\subsection{Comparison between LIRIC and CAMx}

In this section the simulated profiles of CAMx are compared against the observational profiles of LIRIC. The vertical mean profiles derived from LIRIC and CAMx for the $\mathrm{PM}_{2.5}$ and $\mathrm{PM}_{2.5-10}$ particles are displayed in Fig. $4 \mathrm{a}$ and $\mathrm{b}$. The solid lines correspond to the "all" category, while the dashed lines correspond to the "no fires" category, which consists of 16 measurements. It can be seen that the $\mathrm{PM}_{2.5}$ mean concentration profiles show very good agreement between LIRIC and CAMx. The vertical structure is similar. Below $2 \mathrm{~km}$ the model aerosol concentrations are up to $6-$ $7 \mu \mathrm{g} \mathrm{m}^{-3}$ lower compared to LIRIC, while there is a slight 
Hysplit backward trajectories over Thessaloniki

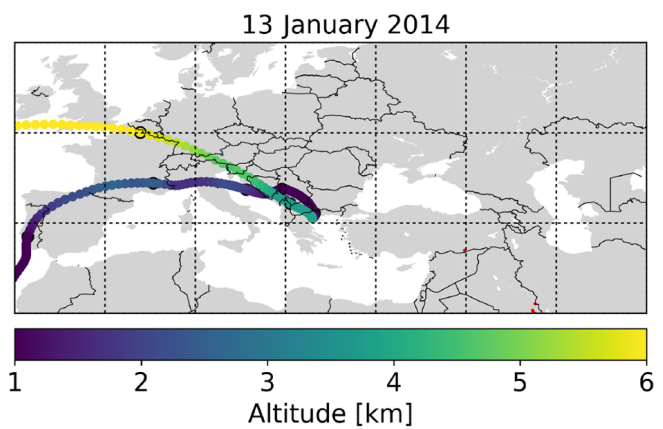

(a)

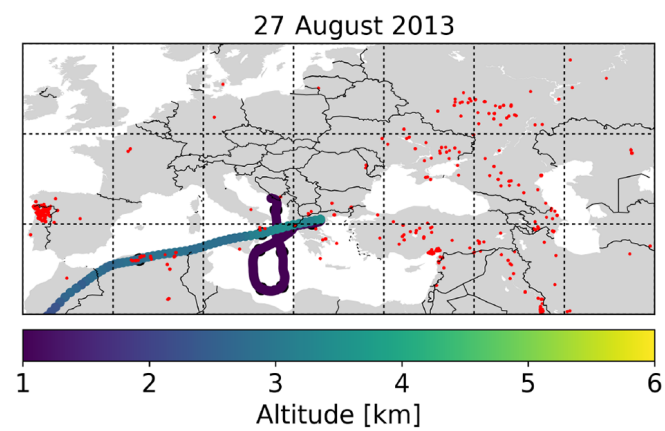

(b)

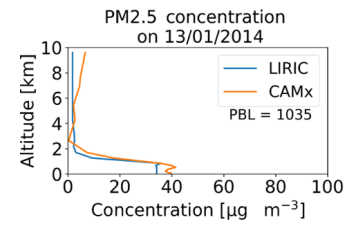

(c)

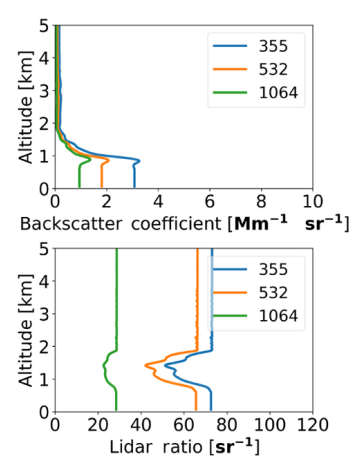

(g)
Concentration profiles over Thessaloniki

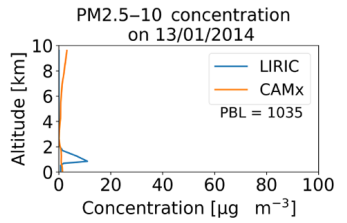

(d)

LIRIC optical profiles over Thessaloniki

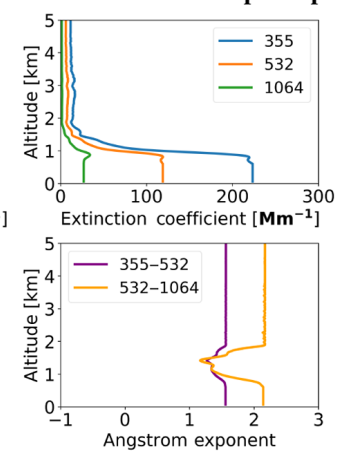

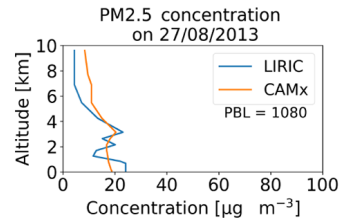

(e)
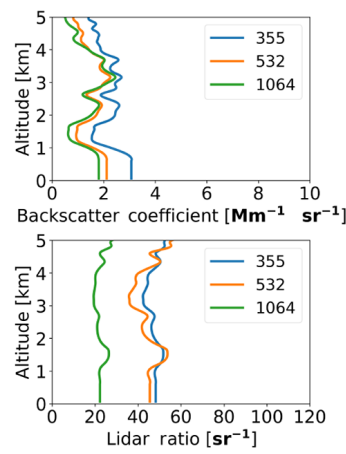

(h)

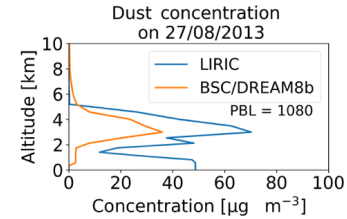

(f)
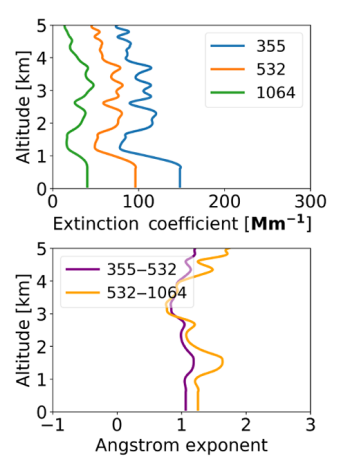

Figure 3. Two sample cases are presented here. The left column corresponds to a continental aerosol case on 13 January 2014 , while the right column corresponds to a dust aerosol case on 27 August 2013. The wind back-trajectories (a, b), the $\mathrm{PM}_{2.5}$ and $\mathrm{PM}_{2.5-10}$ concentration profiles of LIRIC (c, d, e, f), and the respective optical products $(\mathbf{g}, \mathbf{h})$ are included. The big black dots in (a) and (b) indicate $24 \mathrm{~h}$ intervals.

overestimation by the model above $3 \mathrm{~km}$ by $1-2 \mu \mathrm{g} \mathrm{m} \mathrm{m}^{-3}$. Removing the six wildfire cases modifies the LIRIC mean profile towards slightly lower values and the CAMx mean profile towards slightly higher values, leading to discrepancies smaller than $4 \mu \mathrm{g} \mathrm{m}^{-3}$ for the whole profile. Details on the behavior of the model in the boundary layer and the free troposphere for both the "all" and "no fires" categories can be found in the next paragraphs. As far as the $\mathrm{PM}_{2.5-10}$ mode is concerned, it seems to be underestimated by the model below $3 \mathrm{~km}$. The concentration of CAMx stays below $5 \mu \mathrm{g} \mathrm{m}^{-3}$, while LIRIC estimates a mean concentration around $20 \mu \mathrm{g} \mathrm{m}^{-3}$. Above $4 \mathrm{~km}$ this behavior is reversed and the model seems to result in higher aerosol concentrations providing values in the range $5-10 \mu \mathrm{g} \mathrm{m}^{-3}$, while the concentration of LIRIC gradually drops below $2 \mu \mathrm{g} \mathrm{m}^{-3}$. The reasons for the discrepancies in the $\mathrm{PM}_{2.5-10}$ mode could be connected to the model's emissions inventory, the boundary conditions or the transport processes within the simulation domain over long distances. Some insight can be offered by individually inspecting the contribution of each aerosol component in the final product as shown in the next paragraph.

The mean concentration profiles of the aerosol components that comprise the $\mathrm{PM}_{2.5}$ and $\mathrm{PM}_{2.5-10}$ particles of CAMx are presented in Fig. $4 \mathrm{c}$ and d. The aerosol components of Table 1 are grouped into categories that follow the OPAC formalism (Hess et al., 1998). The particulate chloride and sodium components form the "sea salt" category. The aerosol water content, the primary elemental carbon, the Fine Crustal and Coarse Crustal as well as Fine Other Primary and Coarse Other Primary components are independent and form the categories "water", "soot", "soil $\mathrm{PM}_{2.5}$ ", "soil $\mathrm{PM}_{2.5-10}$ ", "other $\mathrm{PM}_{2.5}$ " and "other $\mathrm{PM}_{2.5-10 \text { ", re- }}$ spectively. The particulate nitrate, the sulfate and the particulate ammonium are all hygroscopic and are grouped into the 
LIRIC and CAMx concentration profiles

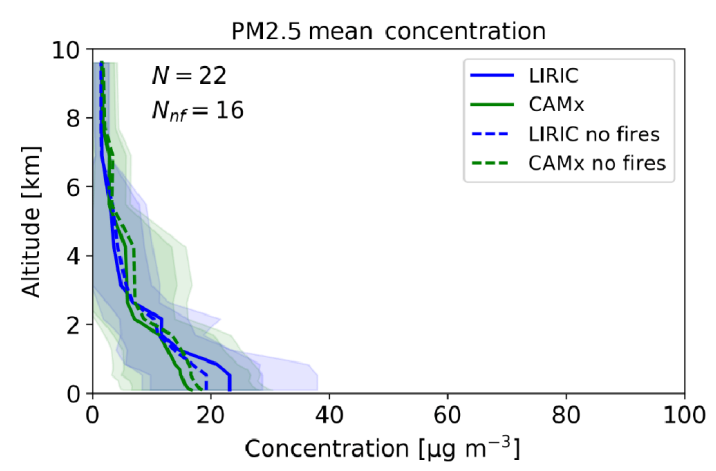

(a)

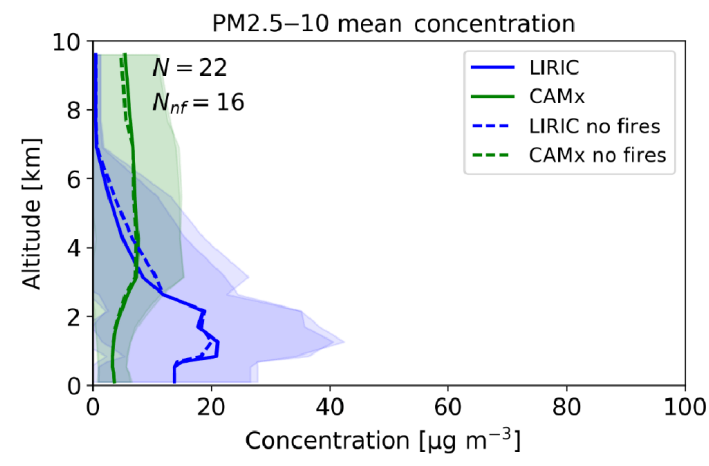

(b)

CAMx aerosol component profiles

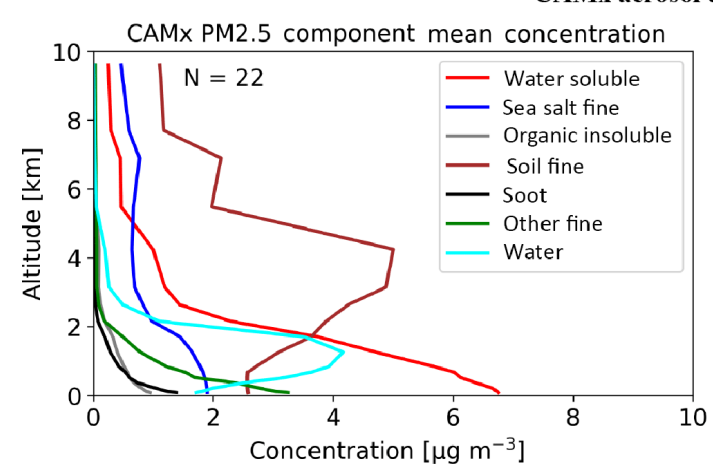

(c)

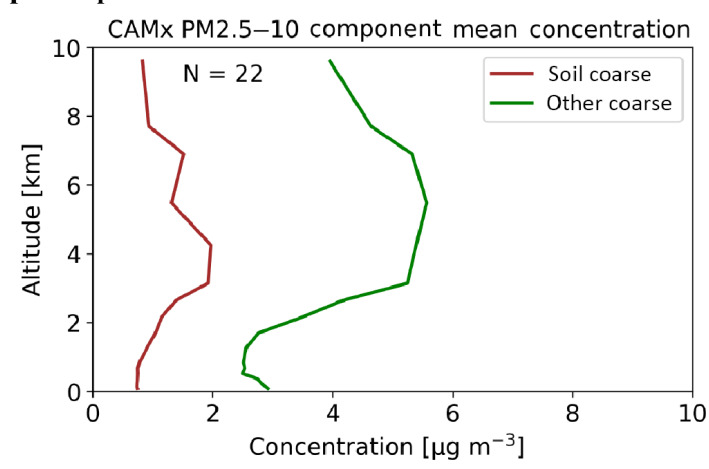

(d)

Figure 4. (a, b) Comparison of the mean $\mathrm{PM}_{2.5}$ (a) and $\mathrm{PM}_{2.5-10}$ (b) aerosol concentration profiles between LIRIC and CAMx in the period 2013-2015. The shaded regions correspond to $1 \sigma$ of each average profile. (c, d) Presentation of the mean concentration profiles per aerosol component of which the model's $\mathrm{PM}_{2.5}$ (c) and $\mathrm{PM}_{2.5-10}$ (d) modes consist (see Table 1).

"water soluble" category. The rest of the species are all organic and are grouped in the "organic insoluble" category. The Fine Other Primary component contains the $\mathrm{PM}_{2.5}$ particles that are not chemically speciated as well as a part of the $\mathrm{PM}_{2.5}$ sea salt that cannot be categorized either as particulate chloride or as sodium. The Coarse Other Primary component contains the $\mathrm{PM}_{2.5-10}$ particles that are chemically speciated, like nitrate, sulfate, ammoniac, elemental carbon and primary organic aerosol, as well as the $\mathrm{PM}_{2.5-10}$ sea salt and all the other $\mathrm{PM}_{2.5-10}$ particles that are not chemically speciated.

The dominant component below $2 \mathrm{~km}$ is the "water soluble" one with maximum concentration values between 6 and $7 \mu \mathrm{g} \mathrm{m}^{-3}$, followed by the water content with a maximum value of $4 \mu \mathrm{g} \mathrm{m}^{-3}$. Above $2 \mathrm{~km}$ the "soil $\mathrm{PM}_{2.5}$ " component becomes significantly stronger, with its maximum of $5 \mu \mathrm{g} \mathrm{m}^{-3}$ located at $3-4 \mathrm{~km}$. As far as the $\mathrm{PM}_{2.5-10}$ are considered, the majority of particles belong to the "other $\mathrm{PM}_{2.5-10}$ " component. The "soil $\mathrm{PM}_{2.5-10}$ " component is systematically lower than the "other $\mathrm{PM}_{2.5-10}$ " component by at least $2 \mu \mathrm{g} \mathrm{m}^{-3}$. Both components could be responsible for the higher values above $4 \mathrm{~km}$ compared to the LIRIC $\mathrm{PM}_{2.5-10}$ mean profiles since the highest values in both com- ponent profiles are located between 3 and $7 \mathrm{~km}$. In order to investigate whether only one of them or both are also responsible for the large bias below $3 \mathrm{~km}$, we isolate the dust component by selecting only the dust cases. This comparison is presented in Sect. 4.2. Below, the center of mass and the integrated mass are calculated in order to further quantify the comparison results.

The center of mass (Table 2) provides information on the height where most of the particles are located. It is presented in LIRIC against CAMx center of mass scatterplots (Fig. 5) for the $\mathrm{PM}_{2.5}$ and $\mathrm{PM}_{2.5-10}$ particles. The least squares fit line and the correlation coefficient for the "no fires" category are displayed in the plots. A synopsis of the center of mass metrics can be seen in Table 3. The "no fires" category is not included for the $\mathrm{PM}_{2.5-10}$ aerosol. LIRIC estimates a mean center of mass value of $2.43 \pm 0.76 \mathrm{~km}$ for the "all" category, which increases slightly for the "no fires" category in the $\mathrm{PM}_{2.5}$ mode. CAMx predicts a somewhat higher mean center of mass at $3.00 \pm 0.83 \mathrm{~km}$ that does not change much if the wildfire cases are excluded. Thus, the resulting mean bias is only $0.57 \mathrm{~km}$ and the fractional bias is $20.9 \%$, and they improve to $0.38 \mathrm{~km}$ and $14.3 \%$, respectively. The root mean square error (RMSE) is $0.81 \mathrm{~km}$ for the "no fires" category. 

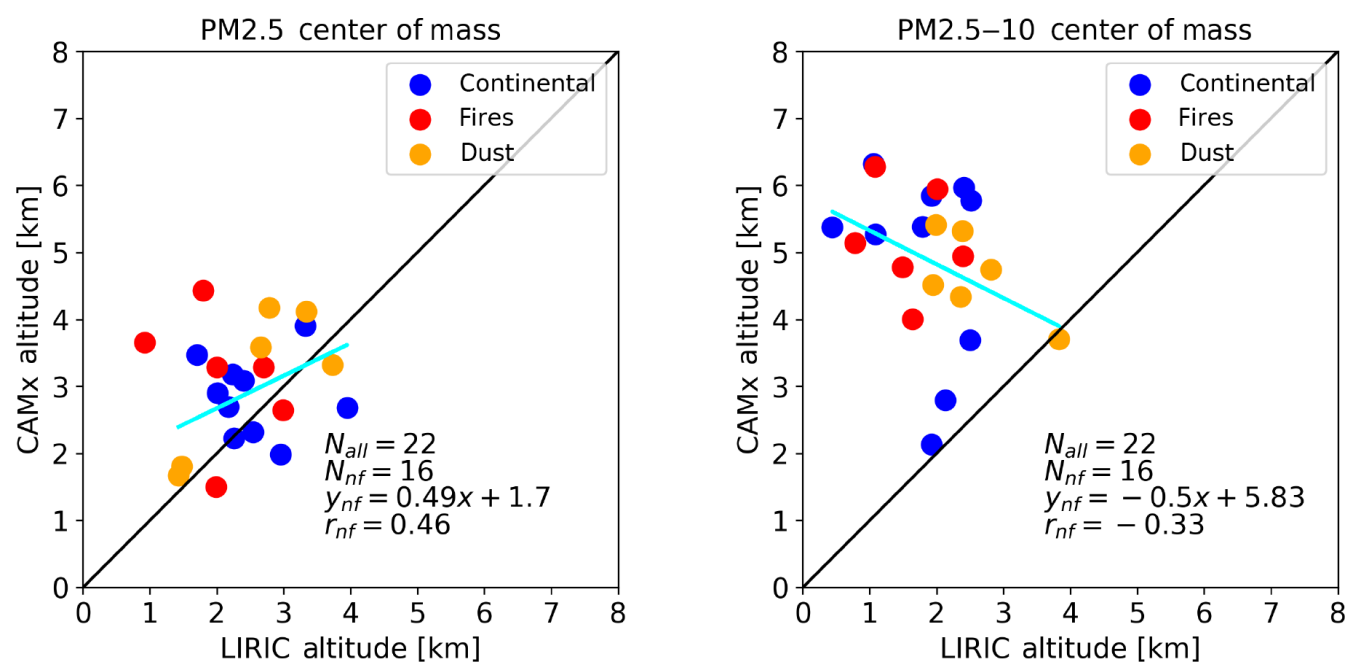

Figure 5. Scatterplots of the $\mathrm{PM}_{2.5}$ (left) and $\mathrm{PM}_{2.5-10}$ (right) center of mass for LIRIC and CAMx in the period 2013-2015. The biomass burning cases are marked with red, while the dust cases are marked with orange. The "nf" label corresponds to metrics of the category "no fires". The least square fit line corresponding to the screened cases (blue and orange) is also included.

Table 3. Center of mass metrics. The category "All" corresponds to the total of the cases (22 in total), while the category "No Fires" refers to the cases that are not classified as wildfires (16 out of 22). The mean, standard deviation, mean bias and root mean square error values are in km units. Pearson's correlation coefficient $(r)$ and the least square fit slope (a) and intercept (b) values are also calculated.

\begin{tabular}{llcccccccc}
\hline Mode & Category & LIRIC mean & CAMx mean & Mean bias & Frac. bias (\%) & RMSE & $r$ & $\mathrm{a}$ & $\mathrm{b}$ \\
\hline $\mathrm{PM}_{2.5}$ & All & $2.43 \pm 0.76$ & $3.00 \pm 0.83$ & 0.57 & 20.9 & 1.02 & 0.19 & 0.21 & 2.49 \\
$\mathrm{PM}_{2.5}$ & No Fires & $2.56 \pm 0.76$ & $2.94 \pm 0.80$ & 0.38 & 14.3 & 0.81 & 0.46 & 0.49 & 1.70 \\
$\mathrm{PM}_{2.5-10}$ & All & $1.93 \pm 0.76$ & $4.89 \pm 1.10$ & 2.96 & 85.8 & 1.53 & -0.34 & -0.49 & 5.84 \\
\hline
\end{tabular}

Consequently, the height where most of the $\mathrm{PM}_{2.5}$ particles are located seems very well predicted by the model. As far as the $\mathrm{PM}_{2.5-10}$ mode is considered, LIRIC gives a mean value of $1.93 \pm 0.76 \mathrm{~km}$, while CAMx predicts the center of mass at $4.89 \pm 1.53 \mathrm{~km}$. As a result, the mean bias and the RMSE are much larger here, which is expected given the discrepancies that were discussed in the previous paragraph. The correlation coefficient for the $\mathrm{PM}_{2.5}$ particles is 0.19 and increases to 0.46 when the wildfire cases are excluded. While the center of mass is useful when examining the vertical distribution and the location of the maximum concentration, it does not provide any insight into the concentration itself. Additional information on the accumulated concentration within an atmospheric region can be provided by calculating the integrated mass.

The comparison of the integrated mass in the boundary layer and the free troposphere is displayed in LIRIC against CAMx integrated mass scatterplots (Fig. 6), and the metrics are presented in Table 4.

The behavior of the model in the boundary layer is examined first. LIRIC estimates a mean integrated mass at $23.6 \pm 18.9 \mathrm{mg} \mathrm{m}^{-2}$ against a CAMx-derived value of $15.7 \pm 12.3 \mathrm{mg} \mathrm{m}^{-2}$ for the "all" category which change to $20.1 \pm 16.3 \mathrm{mg} \mathrm{m}^{-2}$ and $17.6 \pm 12.9 \mathrm{mg} \mathrm{m}^{-2}$, respectively, for the "no fires" category. The mean bias changes from -7.9 to $-2.5 \mathrm{mg} \mathrm{m}^{-2}$ that translates to a fractional bias improvement from -38.2 to $-14.2 \%$. The RMSE improves from 13.7 to $8.1 \mathrm{mg} \mathrm{m}^{-2}$. The correlation coefficient is at 0.69 and the least square fit slope at 0.45 for the "all" category, but they both improve to 0.87 and 0.69 , respectively, when the wildfire cases are removed. The results that occur for the "no fires" category indicate that, in the boundary layer, the lack of wildfire emissions in CAMx should not be neglected.

The behavior of the model in the free troposphere is also quite promising. The correlation of the model in the FT is also very high. The LIRIC mean values are in very good accordance with the mean values of CAMx. By excluding the wild fire cases the correlation improves from 0.72 to 0.89 . Discrepancies in the free troposphere could also be attributed to the fact that the LIRIC profile above the height where the aerosol load is insignificant is considered constant (see Sect. 3.1.1 and 3.2), while the CAMx profile is still active in that region. The effect of excluding the wildfire cases in the PBL comparisons is larger than in the FT ones which indicates a possible preference of the biomass burning layers to arrive in the PBL over Thessaloniki rather than in the free troposphere. 

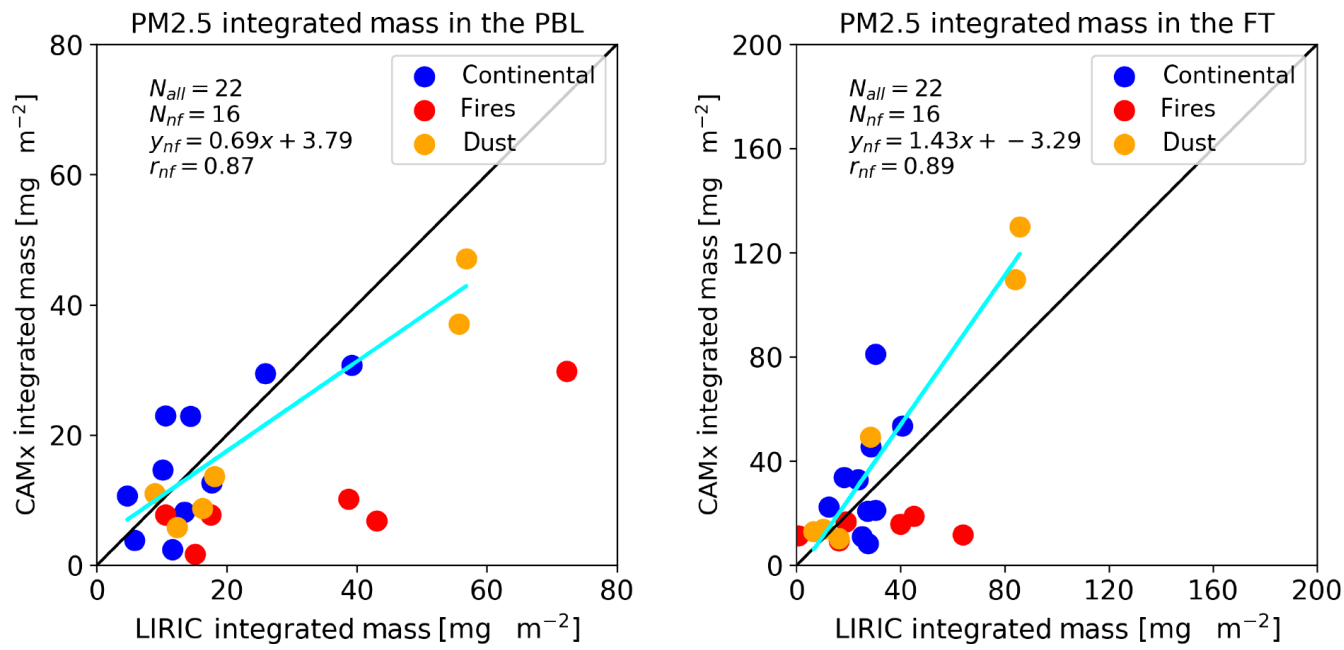

Figure 6. Scatterplots of the $\mathrm{PM}_{2.5}$ integrated mass in the boundary layer (left) and in the free troposphere (right) for LIRIC and CAMx in the period 2013-2015. The biomass burning cases are marked with red, while the dust cases are marked with orange. The "nf" label corresponds to metrics of the category "no fires". The least square fit line corresponding to the screened cases (blue and orange) is also included.

Table 4. $\mathrm{PM}_{2.5}$ integrated mass metrics. Two atmospheric regions are provided. The region below the boundary layer is symbolized as PBL, while the region above it, in the free troposphere, is defined as FT. The category "All" corresponds to the total of the cases (22 in total), while the category "No Fires" refers to the cases that are not classified as wildfires (16 out of 22). The mean, standard deviation, mean bias and root mean square error values are in $\mathrm{mg} \mathrm{m}^{-2}$ units. Pearson's correlation coefficient $(r)$ and the least square fit slope (a) and intercept (b) values are also calculated.

\begin{tabular}{llcccccccc}
\hline Region & Category & LIRIC mean & CAMx mean & Mean bias & Frac. bias (\%) & RMSE & $r$ & $\mathrm{a}$ & $\mathrm{b}$ \\
\hline PBL & All & $23.6 \pm 18.9$ & $15.7 \pm 12.3$ & -7.9 & -38.2 & 13.7 & 0.69 & 0.45 & 5.13 \\
PBL & No Fires & $20.1 \pm 16.3$ & $17.6 \pm 12.9$ & -2.5 & -14.2 & 8.1 & 0.87 & 0.69 & 3.79 \\
FT & All & $30.9 \pm 22.3$ & $33.6 \pm 33.4$ & 2.7 & 2.0 & 23.2 & 0.72 & 1.08 & 0.18 \\
FT & No Fires & $31.0 \pm 22.8$ & $41.0 \pm 36.7$ & 10.1 & 14.9 & 19.4 & 0.89 & 1.43 & -3.29 \\
\hline
\end{tabular}

Taking into account the very good performance of CAMx in both atmospheric regions, it appears to produce somewhat higher values for the aerosol concentration in the boundary layer and somewhat lower values in the free troposphere exhibiting a similar absolute fractional bias between 14 and $15 \%$ and a similar high correlation above 0.85 in both atmospheric regions for the $\mathrm{PM}_{2.5}$ particles. Possible causes of the discrepancies between LIRIC and CAMx, especially for the $\mathrm{PM}_{2.5-10}$ particles, could be the aerosol emission inventory of CAMx, the chemical boundary conditions and the long range aerosol transportation within the CAMx domain. The LIRIC inversion is also subject to uncertainties (see Sect. 2.5) but their effect is certainly not enough to explain the large discrepancies observed for the $\mathrm{PM}_{2.5-10}$ particles. We have shown here that cases that also include wildfire aerosols are a challenge for the model since those emissions are not included at all. It has been stated in Sect. 2 that the soil dust resuspension emissions are also not included and that the Saharan dust emissions are included only as boundary conditions, while the Saharan region is not completely outside the European domain (Fig. 1). The discrepancies in the $\mathrm{PM}_{2.5-10}$ mean profile could be connected to the lack of dust resuspension emissions and Saharan dust emissions within the domain and also with issues associated with the boundary conditions or the transportation of desert dust over long distances. In the next section the behavior of CAMx in transported dust events is analyzed in more detail.

\subsection{Dust case analysis using BSC-DREAM8b}

In this section the products derived by LIRIC are compared against the simulations of both CAMx and BSC-DREAM8b. Out of the initial dataset of 22 measurements, 6 were identified as dust cases. The BSC-DREAM8b model has been previously extensively validated (see Sect. 2.4 ) and is used here solely to support the discussion of the CAMx vs LIRIC comparisons for the $\mathrm{PM}_{2.5-10}$ particles. That being said, we aim to isolate the desert dust component and compare between LIRIC and each model in order to investigate if the observed large discrepancies in the $\mathrm{PM}_{2.5-10}$ products of CAMx are also present in the simulations of a model that specializes in desert dust. While it is feasible to get the $\mathrm{PM}_{2.5-10}$ dust profile with CAMx from the $\mathrm{PM}_{2.5-10}$ profile by selecting 

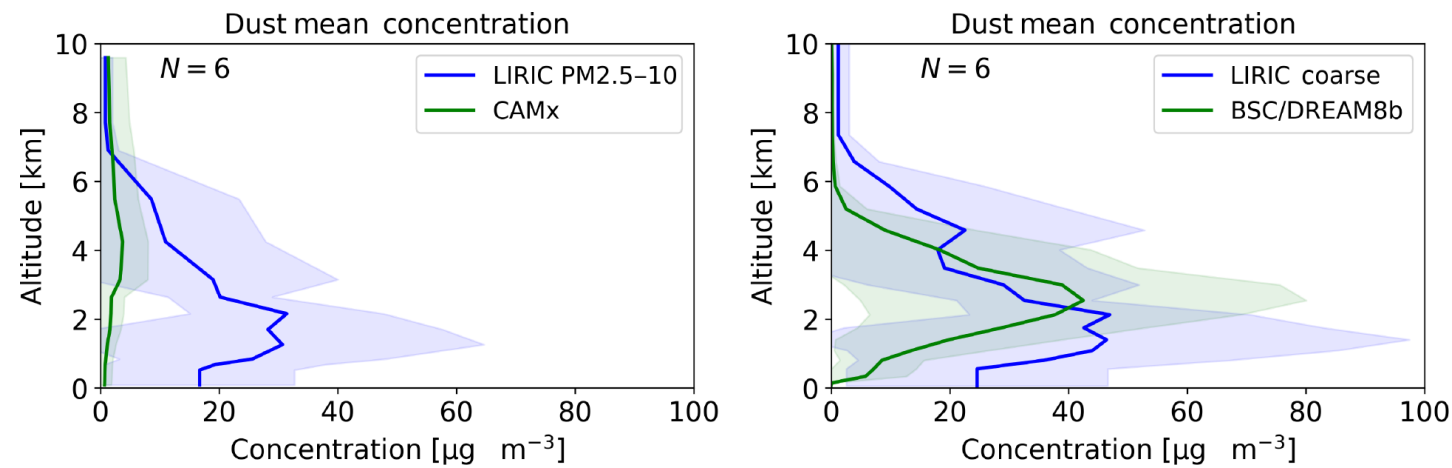

Figure 7. Comparison of CAMX (left) and BSC-DREAM8b (right) mean dust concentration profiles with LIRIC in the period $2013-2015$. The mean $\mathrm{PM}_{2.5-10}$ profile from LIRIC is compared with the mean soil $\mathrm{PM}_{2.5-10}$ component profile from CAMx. The mean total dust profile from BSC-DREAM8b is compared against the coarse profile of LIRIC. The shaded regions correspond to $1 \sigma$ of each average profile. Differences between the LIRIC profiles are attributed to the interpolation of LIRIC in the resolution of each model.

only the "soil $\mathrm{PM}_{2.5-10 "}$ " component (Table 1), this is not the case for LIRIC. Having applied the aerosol characterization of Sect. 3.1.2, it is reasonable to assume that the coarse mode, which also includes the $\mathrm{PM}_{2.5-10}$ particles, of the selected dust cases is almost entirely attributed to dust. Binietoglou et al. (2015) also use a dataset of measurements that were flagged as desert dust in order to compare between the observations and the simulations of the dust transportation models. Isolating either the coarse or the $\mathrm{PM}_{2.5-10}$ dust of BSC-DREAM8b is also challenging because this model provides total dust profiles. d'Almeida (1987) mentions that the contribution of the fine dust should be low, especially near where it is emitted. Mamouri and Ansmann (2014) have separated the fine and coarse mode dust profiles during an outbreak event. They report that while the fine dust contribution in the mass concentration was significant near the ground in that transported dust case, it stayed well below $20 \%$ of the total concentration above $400 \mathrm{~m}$. Consequently, the use of the total dust profile of BSC-DREAM8b should not jeopardize much the validity of the comparison with LIRIC, especially in the free troposphere.

In Sect. 2.1.1 we describe a procedure to convert the coarse profiles of LIRIC to $\mathrm{PM}_{2.5-10}$ (Eqs. 2 and 3). While this conversion is convenient for the comparison between LIRIC and CAMx this is not the case for the dust specialized model. As was mentioned above, the retrievals of BSC-DREAM8b are comparable with the coarse profile of LIRIC for the desert dust cases. For this reason the coarse profile of LIRIC will be used in the comparison with BSC-DREAM8b, while the $\mathrm{PM}_{2.5-10}$ profile of LIRIC will be used in the comparison with CAMx.

The mean profiles of the dust aerosol mass concentration is presented in Fig. 7. The comparison between CAMx and LIRIC for the $\mathrm{PM}_{2.5-10}$ particles can be seen on the left, while the comparison between BSC-DREAM8b and LIRIC for the coarse particles is presented on the right. It is obvious that CAMx underestimates the concentration by providing values that never exceed $10 \mu \mathrm{g} \mathrm{m}{ }^{-3}$, while the LIRIC mean values rise up to $30 \mathrm{\mu g} \mathrm{m}^{-3}$ and potentially much higher for selective cases. However, above $4 \mathrm{~km}$ there seems to be some structural agreement between the two profiles and above $7 \mathrm{~km}$ the small values of the LIRIC profile are successfully reproduced by CAMx. This results in a center of mass predicted by CAMx for the "soil $\mathrm{PM}_{2.5-10}$ " around $4 \mathrm{~km}$. Consequently, the overestimation above $4 \mathrm{~km}$ in Fig. $4 \mathrm{~b}$, which was discussed in Sect. 4.1, is probably associated mainly with the "other $\mathrm{PM}_{2.5-10}$ " component since this behavior does not occur here. Despite the large negative bias this structural agreement results in a correlation coefficient of 0.63 in the FT between CAMx and LIRIC integrated mass.

On the other hand, BSC-DREAM $8 \mathrm{~b}$ mean values are close to the ones derived by LIRIC between 2 and $4 \mathrm{~km}$, ranging between 20 and $40 \mu \mathrm{g} \mathrm{m}^{-3}$. Below $2 \mathrm{~km}$, even BSCDREAM8b seems to underestimate the concentration. This could be attributed to mixing with $\mathrm{PM}_{2.5-10}$ particles other than desert dust in this region. This scenario is further supported by taking into account the "dust" category trajectories that arrive in the PBL (Fig. 2c) in Sect. 3.3. In the next paragraphs the center of mass and the integrated mass comparison are presented in a way similar to Sect. 4.1.

The center of mass comparison between LIRIC and BSCDREAM8b is presented in Fig. 8a accompanied by the observational and modeled metrics in Table 5. The center of mass value of BSC-DREAM8b is at $2.60 \pm 0.54 \mathrm{~km}$ which is quite close to the LIRIC estimates resulting in a mean bias of $0.03 \mathrm{~km}$ and a fractional bias of $0.2 \%$. The correlation coefficient and the least square fit slope values are at 0.17 and 0.31 , respectively, between the algorithm and the air quality model, but they improve at 0.57 and 0.41 when the dust transportation model is used instead. Binietoglou et al. (2015) estimate a correlation coefficient of 0.38 for the same model and for a dataset of 69 dust profiles.

As far as the integrated mass is considered, the comparison of LIRIC vs BSC-DREAM8b is also presented in Fig. 8, the 


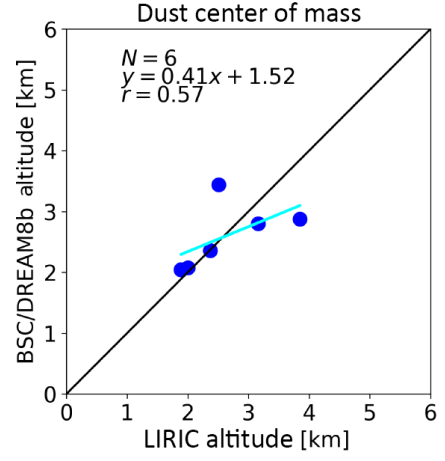

(a)

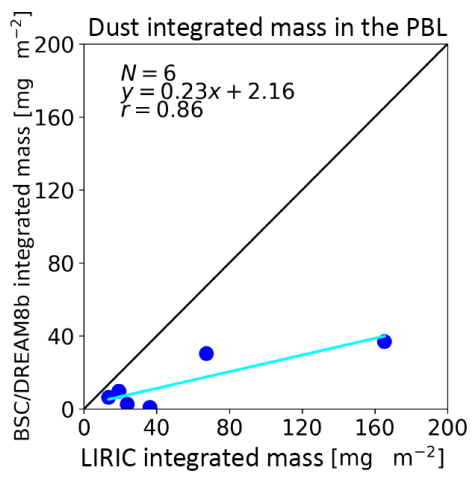

(b)

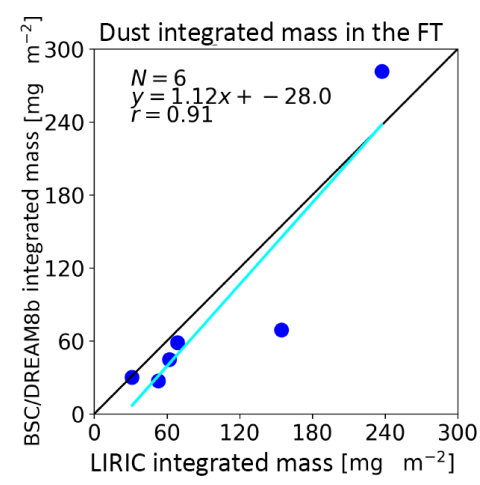

(c)

Figure 8. (a) Scatterplots of the center of mass of the dust cases for BSC-DREAM8b. (b) Scatterplots of the integrated mass of the dust cases for BSC-DREAM8b in the boundary layer. (c) Scatterplots of the integrated mass of the dust cases for BSC-DREAM8b in the free troposphere. The least square fit line is also included. The correlation coefficient for those cases is provided as well. The figure corresponds to the dust cases of the period 2013-2015.

Table 5. Dust center of mass metrics. Metrics for the two models and LIRIC are provided. A total of 6 out of 22 cases are included in the category "dust". Differences in the LIRIC values per model are attributed to the interpolation in different vertical resolution depending on the model. The mean, standard deviation, mean bias and root mean square error values are in km units. Pearson's correlation coefficient ( $r$ ) and the least square fit slope (a) and intercept (b) values are also calculated.

\begin{tabular}{llcccccccc}
\hline Model & LIRIC mode & LIRIC mean & Model mean & Mean bias & Frac. bias (\%) & RMSE & $r$ & $\mathrm{a}$ & $\mathrm{b}$ \\
\hline CAMx & $\mathrm{PM}_{2.5-10}$ & $2.55 \pm 0.70$ & $4.04 \pm 1.28$ & 1.48 & 41.6 & 1.35 & 0.17 & 0.31 & 3.25 \\
DREAM & Coarse & $2.63 \pm 0.75$ & $2.60 \pm 0.54$ & -0.03 & 0.2 & 0.63 & 0.57 & 0.41 & 1.52 \\
\hline
\end{tabular}

boundary layer in Fig. 8b and the free tropospheric region in Fig. 8c. The agreement is best in the free tropospheric region for the dust specialized model which is in accordance with the profiles of Fig. 7. The mean values for BSC-DREAM8b in the FT are $85.3 \pm 97.5 \mathrm{mg} \mathrm{m}^{-2}$. They are quite close to the mean values of LIRIC at $101.2 \pm 79.1 \mathrm{mg} \mathrm{m}^{-2}$ resulting to the lowest absolute mean bias of Table 6 at $-15.9 \mathrm{mg} \mathrm{m}^{-2}$ and a fractional error of $-29.1 \%$. The correlation between LIRIC and BSC-DREAM8b in the same region is high, at 0.91 , and the least square fit slope is 1.12 , in contrast to the PBL region, where the slope is much lower at 0.23 despite the correlation being similar. Binietoglou et al. (2015) report a correlation of 0.54 for the integrated dust concentration in the whole profile for their dataset of 69 measurements. As has already been mentioned, discrepancies between the algorithm and the models can occur from the non-dust-aerosol component. This can be crucial for the PBL region, where particles from various sources are mixed.

The comparisons between LIRIC and the two models highlight the differences between BSC-DREAM8b and CAMx in the free troposphere for the dust cases. The dust specialized model was able to reproduce values similar to the observations, leading to the conclusion that the "soil $\mathrm{PM}_{2.5-10}$ " component of CAMx is definitely underestimated, especially below $4 \mathrm{~km}$. This behavior could be linked to the model's lack of direct Saharan dust emissions within the domain (see Sect. 2.3) as well as issues associated with the boundary conditions or transportation of dust over long distances. With the current dataset of six cases, however, it is not clear which of these mechanisms is the prevalent source of bias in the dust profiles of CAMx. However, we have to mention here that the two models are quite different concerning the parametrization of the size distribution of the soil dust and thus a direct quantitative comparison is not meaningful. Having said that, the desert dust cases are not the majority and by removing the 6 dust cases out of the 22 total cases did not improve much the $\mathrm{PM}_{2.5-10}$ profile of CAMx. The comparison for the $\mathrm{PM}_{2.5}$ particles is actually affected in a negative way due to the limited number of measurements in the dataset. In order to explain these biases (Sect. 4.1) we have to assume that the "other $\mathrm{PM}_{2.5-10}$ " component is also biased, most probably underestimated below $4 \mathrm{~km}$ and overestimated above. This component contains the $\mathrm{PM}_{2.5-10}$ sea salt and also the $\mathrm{PM}_{2.5-10}$ ammoniac, sulfate and nitrate particles (see Table 1 and Sect. 4.1) that are all supposed to be hygroscopic. Despite that, the "other $\mathrm{PM}_{2.5-10}$ " component is not treated as hygroscopic by the model. Therefore, the water absorption and the hygroscopic growth of the $\mathrm{PM}_{2.5-10}$ particles are not taken into account at all. Consequently, the absence of any water content in the $\mathrm{PM}_{2.5-10}$ particles of CAMx could lead to an underestimation of the model since 
Table 6. Dust integrated mass metrics. Metrics for the two models in two atmospheric regions are provided. The region below the boundary layer is symbolized as the PBL, while the region above it, in the free troposphere, is defined as FT. A total of 6 out of 22 cases are included in the category "dust". The mean, standard deviation, mean bias and root mean square error values are in mg m ${ }^{-2}$ units. Pearson's correlation coefficient $(r)$ and the least square fit slope (a) and intercept (b) values are also calculated.

\begin{tabular}{lllcccccccc}
\hline Model & Region & LIRIC mode & LIRIC mean & Model mean & Mean bias & Frac. bias $(\%)$ & RMSE & $r$ & $\mathrm{a}$ & $\mathrm{b}$ \\
\hline CAMx & PBL & PM $_{2.5-10}$ & $34.7 \pm 38.0$ & $0.8 \pm 0.9$ & -33.8 & -189.5 & 37.6 & 0.46 & 0.01 & 0.43 \\
DREAM & PBL & Coarse & $54.2 \pm 57.7$ & $14.5 \pm 15.3$ & -39.7 & -114.5 & 45.2 & 0.86 & 0.23 & 2.16 \\
CAMx & FT & PM $_{2.5-10}$ & $65.4 \pm 56.8$ & $18.4 \pm 26.9$ & -47.0 & -139.0 & 44.9 & 0.63 & 0.30 & -1.20 \\
DREAM & FT & Coarse & $101.2 \pm 79.1$ & $85.3 \pm 97.5$ & -15.9 & -29.1 & 42.0 & 0.91 & 1.12 & -28.00 \\
\hline
\end{tabular}

LIRIC concentration profiles include the water content absorbed by the $\mathrm{PM}_{2.5}$ and $\mathrm{PM}_{2.5-10}$ particles.

\section{Conclusions}

The use of LIRIC in the evaluation of CAMx resulted in very good quantitative and qualitative agreement for the $\mathrm{PM}_{2.5}$ aerosol profiles. The mean model profiles are in the same order of magnitude and show a similar vertical distribution with the observational ones for the $\mathrm{PM}_{2.5}$ particles. The mean center of mass of the model is different by only $0.57 \mathrm{~km}$ from the respective value of the LIRIC which translates to a mean fractional bias of $20.9 \%$. The integrated mass comparison indicates very good performance of the model both in the boundary layer and in the free troposphere, with absolute fractional biases below $15 \%$ and correlation coefficients above 0.85 within the PBL and the FT. All things considered, there are strong indications that the lack of wildfire emissions in CAMx affects the comparisons concerning the mass concentration of the $\mathrm{PM}_{2.5}$ particles that arrive in the boundary layer. When those cases are excluded, the correlation between the model simulations and the observational data is very good, indicating that the model succeeds in representing most other $\mathrm{PM}_{2.5}$ sources and related processes.

The $\mathrm{PM}_{2.5-10}$ mean profile of CAMx, on the other hand seems to be underestimated below $4 \mathrm{~km}$ and overestimated above. Consequently, the vertical structure shows differences with the observational data. Concerning more specifically the behavior of the "soil $\mathrm{PM}_{2.5-10}$ " component of CAMx, this was evaluated using selected dust cases and the BSCDREAM8b desert dust dispersion model.

It was shown that CAMx underestimates the concentration by providing values that never exceed $10 \mu \mathrm{g} \mathrm{m}^{-3}$, while the LIRIC mean values rise up to $30 \mu \mathrm{g} \mathrm{m}^{-3}$ and potentially much higher for selective cases. This behavior is supposed to be linked to the model's lack of direct Saharan dust emissions within the domain as well as issues associated with the boundary conditions and the transportation of dust over long distances. The relative structural agreement observed between the two profiles result in a correlation coefficient of 0.63 in the FT between CAMx and LIRIC integrated mass. On the other hand, BSC-DREAM8b mean values are close to the ones derived by LIRIC between 2 and $4 \mathrm{~km}$, ranging between 20 and $40 \mathrm{\mu g} \mathrm{m}^{-3}$, and also show similar vertical structures.

Furthermore, since the small number of dust cases ( 6 out of 22) is not enough to explain the large discrepancies in the $\mathrm{PM}_{2.5-10}$ mode between LIRIC and CAMx, it is likely that the "other $\mathrm{PM}_{2.5-10}$ " component is also biased. This could be linked to the fact that it consists of many subcomponents, some of which in theory are hygroscopic, like the $\mathrm{PM}_{2.5-10}$ sea salt, but they are not treated as such by the model, possibly leading to underestimations in the aerosol concentration.

This study shows that the LIRIC code, based on the synergy of sunphotometer and lidar measurements, can be used in order to evaluate an air quality model like CAMx as far as the aerosol mass concentration is considered. Furthermore, models specialized in particular types of emissions, like the BSC-DREAM8b dust transportation model, can be used along with LIRIC in order to help isolate one specific aerosol component that the air quality models provide or completely lack. That way, the components can be tested individually, making it possible to directly associate biases with a specific type of emission. In this study, for example, we concluded that the lack of a wildfire component, the desert dust component and the remaining $\mathrm{PM}_{2.5-10}$ component are all potential sources of bias in the modeled aerosol concentration profiles. The emissions that are associated with these aerosol types can then be examined and proper corrections could be applied in order to improve the overall performance of the model. Finally, if such comparisons are successful, then the simulations of the model can also be utilized in the aerosol classification procedure of the lidar measurements since the individual aerosol components of the model could provide insight into the origin of the main aerosol layers. 
Data availability. The lidar data used in this study as input to LIRIC are available upon registration at http://data.earlinet.org. All the trajectories were compiled using the free online version of the HYSPLIT model available at http://ready.arl.noaa. gov/HYSPLIT.php. The fire spot data from the MODIS satellite instrument have been extracted from the Collection 6 product (MCD14ML) and they are available at https://firms.modaps. eosdis.nasa.gov/download/. The dust profiles, simulated by the DREAMBSC8b model, are available at http://www.bsc.es/ESS/ bsc-dust-daily-forecast. The modeling simulations from CAMx are available from the authors upon request.

Competing interests. The authors declare that they have no conflict of interest.

Acknowledgements. The authors would like to acknowledge the EU projects MACC-III (Monitoring Atmospheric Composition and Climate - III, grant agreement no. 633080) and MACC-II project (Monitoring Atmospheric Composition and Climate - Interim Implementation, grant agreement no. 283576). The simulated results presented in this research paper have been produced using the EGI and HellasGrid infrastructures. The ACTRIS-2 project from the European Union's Horizon 2020 research and innovation programme under grant agreement no. 654109 is gratefully acknowledged. The authors would also like to acknowledge the support provided by the Scientific Computing Center at Aristotle University of Thessaloniki throughout the progress of the work on air quality forecasting. BSC-DREAM8b simulations were performed on the Mare Nostrum supercomputer hosted by Barcelona Supercomputing Center-Centro Nacional de Supercomputacion (BSC-CNS). S. Basart wants to acknowledge the CICYT project (CGL2013-46736). Elina Giannakaki acknowledges the support of the Academy of Finland (project no. 270108).

Edited by: A. Ansmann

Reviewed by: three anonymous referees

\section{References}

Amiridis, V., Balis, D. S., Kazadzis, S., Bais, A., Giannakaki, E., Papayannis, A., and Zerefos, C.: Four-year aerosol observations with a Raman lidar at Thessaloniki, Greece, in the framework of European Aerosol Research Lidar Network (EARLINET), J. Geophys. Res.-Atmos., 110, d21203, https://doi.org/10.1029/2005JD006190, 2005.

Amiridis, V., Kafatos, M., Perez, C., Kazadzis, S., Gerasopoulos, E., Mamouri, R. E., Papayannis, A., Kokkalis, P., Giannakaki, E., Basart, S., Daglis, I., and Zerefos, C.: The potential of the synergistic use of passive and active remote sensing measurements for the validation of a regional dust model, Ann. Geophys., 27, 3155-3164, https://doi.org/10.5194/angeo-27-3155-2009, 2009.

Amiridis, V., Wandinger, U., Marinou, E., Giannakaki, E., Tsekeri, A., Basart, S., Kazadzis, S., Gkikas, A., Taylor, M., Baldasano, J., and Ansmann, A.: Optimizing CALIPSO Saharan dust retrievals, Atmos. Chem. Phys., 13, 12089-12106, https://doi.org/10.5194/acp-13-12089-2013, 2013.
Baars, H., Ansmann, A., Engelmann, R., and Althausen, D.: Continuous monitoring of the boundary-layer top with lidar, Atmos. Chem. Phys., 8, 7281-7296, https://doi.org/10.5194/acp-8-72812008, 2008.

Balis, D. S., Amiridis, V., Nickovic, S., Papayannis, A., and Zerefos, C.: Optical properties of Saharan dust layers as detected by a Raman lidar at Thessaloniki, Greece, Geophys. Res. Lett., 31, 113104, https://doi.org/10.1029/2004GL019881, 2004.

Basart, S., Pérez, C., Cuevas, E., Baldasano, J. M., and Gobbi, G. P.: Aerosol characterization in Northern Africa, Northeastern Atlantic, Mediterranean Basin and Middle East from direct-sun AERONET observations, Atmos. Chem. Phys., 9, 8265-8282, https://doi.org/10.5194/acp-9-8265-2009, 2009.

Basart, S., Pay, M. T., Jorba, O., Pérez, C., Jiménez-Guerrero, P., Schulz, M., and Baldasano, J. M.: Aerosols in the CALIOPE air quality modelling system: evaluation and analysis of PM levels, optical depths and chemical composition over Europe, Atmos. Chem. Phys., 12, 3363-3392, https://doi.org/10.5194/acp12-3363-2012, 2012a.

Basart, S., Pérez, C., Nickovic, S., Cuevas, E., and Baldasano, J.: Development and evaluation of the BSCDREAM8b dust regional model over Northern Africa, the Mediterranean and the Middle East, Tellus B, 64, 18539, https://doi.org/10.3402/tellusb.v64i0.18539, 2012 b.

Binietoglou, I., Basart, S., Alados-Arboledas, L., Amiridis, V., Argyrouli, A., Baars, H., Baldasano, J. M., Balis, D., Belegante, L., Bravo-Aranda, J. A., Burlizzi, P., Carrasco, V., Chaikovsky, A., Comerón, A., D’Amico, G., Filioglou, M., Granados-Muñoz, M. J., Guerrero-Rascado, J. L., Ilic, L., Kokkalis, P., Maurizi, A., Mona, L., Monti, F., Muñoz-Porcar, C., Nicolae, D., Papayannis, A., Pappalardo, G., Pejanovic, G., Pereira, S. N., Perrone, M. R., Pietruczuk, A., Posyniak, M., Rocadenbosch, F., Rodríguez-Gómez, A., Sicard, M., Siomos, N., Szkop, A., Terradellas, E., Tsekeri, A., Vukovic, A., Wandinger, U., and Wagner, J.: A methodology for investigating dust model performance using synergistic EARLINET/AERONET dust concentration retrievals, Atmos. Meas. Tech., 8, 3577-3600, https://doi.org/10.5194/amt-8-3577-2015, 2015.

Böckmann, C.: Hybrid regularization method for the ill-posed inversion of multiwavelength lidar data in the retrieval of aerosol size distributions, Appl. Optics, 40, 1329-1342, https://doi.org/10.1364/AO.40.001329, 2001.

Bovchaliuk, V., Goloub, P., Podvin, T., Veselovskii, I., Tanre, D., Chaikovsky, A., Dubovik, O., Mortier, A., Lopatin, A., Korenskiy, M., and Victori, S.: Comparison of aerosol properties retrieved using GARRLiC, LIRIC, and Raman algorithms applied to multi-wavelength lidar and sun/sky-photometer data, Atmos. Meas. Tech., 9, 3391-3405, https://doi.org/10.5194/amt-9-33912016, 2016.

Bravo-Aranda, J. A., de-Arruda-Moreira, G., Navas-Guzmán, F., Granados-Muñoz, M. J., Guerrero-Rascado, J. L., PozoVázquez, D., Arbizu-Barrena, C., Olmo, F. J., Mallet, M., and Alados-Arboledas, L.: PBL height estimation based on lidar depolarisation measurements (POLARIS), Atmos. Chem. Phys. Discuss., https://doi.org/10.5194/acp-2016-718, in review, 2016.

Brooks, I. M.: Finding Boundary Layer Top: Application of a Wavelet Covariance Transform to Lidar Backscatter Profiles, J. Atmos. Ocean. 
Tech., 20, 1092-1105, https://doi.org/10.1175/15200426(2003)020<1092:FBLTAO>2.0.CO;2, 2003.

Bukowiecki, N., Zieger, P., Weingartner, E., Jurányi, Z., Gysel, M., Neininger, B., Schneider, B., Hueglin, C., Ulrich, A., Wichser, A., Henne, S., Brunner, D., Kaegi, R., Schwikowski, M., Tobler, L., Wienhold, F. G., Engel, I., Buchmann, B., Peter, T., and Baltensperger, U.: Ground-based and airborne in-situ measurements of the Eyjafjallajökull volcanic aerosol plume in Switzerland in spring 2010, Atmos. Chem. Phys., 11, 10011-10030, https://doi.org/10.5194/acp-11-10011-2011, 2011.

Chaikovsky, A., Dubovik, O., Holben, B., Bril, A., Goloub, P., Tanré, D., Pappalardo, G., Wandinger, U., Chaikovskaya, L., Denisov, S., Grudo, J., Lopatin, A., Karol, Y., Lapyonok, T., Amiridis, V., Ansmann, A., Apituley, A., Allados-Arboledas, L., Binietoglou, I., Boselli, A., D'Amico, G., Freudenthaler, V., Giles, D., Granados-Muñoz, M. J., Kokkalis, P., Nicolae, D., Oshchepkov, S., Papayannis, A., Perrone, M. R., Pietruczuk, A., Rocadenbosch, F., Sicard, M., Slutsker, I., Talianu, C., De Tomasi, F., Tsekeri, A., Wagner, J., and Wang, X.: Lidar-Radiometer Inversion Code (LIRIC) for the retrieval of vertical aerosol properties from combined lidar/radiometer data: development and distribution in EARLINET, Atmos. Meas. Tech., 9, 1181-1205, https://doi.org/10.5194/amt-9-1181-2016, 2016.

Chang, J. S., Brost, R. A., Isaksen, I. S. A., Madronich, S., Middleton, P., Stockwell, W. R., and Walcek, C. J.: A threedimensional Eulerian acid deposition model: Physical concepts and formulation, J. Geophys. Res.-Atmos., 92, 14681-14700, https://doi.org/10.1029/JD092iD12p14681, 1987.

d'Almeida, G. A.: On the variability of desert aerosol radiative characteristics, J. Geophys. Res.-Atmos., 92, 3017-3026, https://doi.org/10.1029/JD092iD03p03017, 1987.

Dubovik, O. and King, M. D.: A flexible inversion algorithm for retrieval of aerosol optical properties from Sun and sky radiance measurements, J. Geophys. Res.-Atmos., 105, 20673-20696, https://doi.org/10.1029/2000JD900282, 2000.

Dubovik, O., Sinyuk, A., Lapyonok, T., Holben, B. N., Mishchenko, M., Yang, P., Eck, T. F., Volten, H., Muñoz, O., Veihelmann, B., van der Zande, W. J., Leon, J.-F., Sorokin, M., and Slutsker, I.: Application of spheroid models to account for aerosol particle nonsphericity in remote sensing of desert dust, J. Geophys. Res.Atmos., 111, d11208, https://doi.org/10.1029/2005JD006619, 2006.

EEA: EMEP/CORINAIR Emission Inventory Guidebook - 2006, Tech. Rep. 11/2006, European Environmental Agency, 2006.

ENVIRON 2010: User's Guide CAMx Comprehensive Air Quality Model with Extensions., Version 5.30, ENVIRON International Corporation, 2010.

Filioglou, M., Siomos, N., Poupkou, A., S., D., Chaikovsky, A., and Balis, D. S.: A sensitivity study of the LIdar-Radiometer Inversion Code (LIRIC) using selected cases from Thessaloniki database, Int. J. Remote Sens., in review, 2017.

Flamant, C., Pelon, J., Flamant, P. H., and Durand, P.: Lidar determination of the entrainment zone thickness at the top of the unstable marine atmospheric boundary layer, Bound.-Lay. Meteorol., 83, 247-284, https://doi.org/10.1023/A:1000258318944, 1997.

Flemming, J., Inness, A., Flentje, H., Huijnen, V., Moinat, P., Schultz, M. G., and Stein, O.: Coupling global chemistry transport models to ECMWF's integrated forecast system, Geosci.
Model Dev., 2, 253-265, https://doi.org/10.5194/gmd-2-2532009, 2009.

Gama, C., Tchepel, O., Baldasano, J. M., Basart, S., Ferreira, J., Pio, C., Cardoso, J., and Borrego, C.: Seasonal patterns of Saharan dust over Cape Verde - a combined approach using observations and modelling, Tellus B, 67, 24410, https://doi.org/10.3402/tellusb.v67.24410, 2015.

Georgoulias, A. K., Papanastasiou, D. K., Melas, D., Amiridis, V., and Alexandri, G.: Statistical analysis of boundary layer heights in a suburban environment, Meteorol. Atmos. Phys., 104, 103111, https://doi.org/10.1007/s00703-009-0021-z, 2009.

Giannakaki, E., Balis, D. S., Amiridis, V., and Zerefos, C.: Optical properties of different aerosol types: seven years of combined Raman-elastic backscatter lidar measurements in Thessaloniki, Greece, Atmos. Meas. Tech., 3, 569-578, https://doi.org/10.5194/amt-3-569-2010, 2010.

Gobbi, G. P., Angelini, F., Barnaba, F., Costabile, F., Baldasano, J. M., Basart, S., Sozzi, R., and Bolignano, A.: Changes in particulate matter physical properties during Saharan advections over Rome (Italy): a four-year study, 2001-2004, Atmos. Chem. Phys., 13, 7395-7404, https://doi.org/10.5194/acp13-7395-2013, 2013.

Granados-Muñoz, M. J., Guerrero-Rascado, J. L., Bravo-Aranda, J. A., Navas-Guzmán, F., Valenzuela, A., Lyamani, H., Chaikovsky, A., Wandinger, U., Ansmann, A., Dubovik, O., Grudo, J. O., and Alados-Arboledas, L.: Retrieving aerosol microphysical properties by Lidar-Radiometer Inversion Code (LIRIC) for different aerosol types, J. Geophys. Res.-Atmos., 119, 4836-4858, https://doi.org/10.1002/2013JD021116, 2014.

Granados-Muñoz, M. J., Bravo-Aranda, J. A., Baumgardner, D., Guerrero-Rascado, J. L., Pérez-Ramírez, D., Navas-Guzmán, F., Veselovskii, I., Lyamani, H., Valenzuela, A., Olmo, F. J., Titos, G., Andrey, J., Chaikovsky, A., Dubovik, O., Gil-Ojeda, M., and Alados-Arboledas, L.: A comparative study of aerosol microphysical properties retrieved from ground-based remote sensing and aircraft in situ measurements during a Saharan dust event, Atmos. Meas. Tech., 9, 1113-1133, https://doi.org/10.5194/amt9-1113-2016, 2016a.

Granados-Muñoz, M. J., Navas-Guzmán, F., Guerrero-Rascado, J. L., Bravo-Aranda, J. A., Binietoglou, I., Pereira, S. N., Basart, S., Baldasano, J. M., Belegante, L., Chaikovsky, A., Comerón, A., D’Amico, G., Dubovik, O., Ilic, L., Kokkalis, P., Muñoz-Porcar, C., Nickovic, S., Nicolae, D., Olmo, F. J., Papayannis, A., Pappalardo, G., Rodríguez, A., Schepanski, K., Sicard, M., Vukovic, A., Wandinger, U., Dulac, F., and AladosArboledas, L.: Profiling of aerosol microphysical properties at several EARLINET/AERONET sites during the July 2012 ChArMEx/EMEP campaign, Atmos. Chem. Phys., 16, 70437066, https://doi.org/10.5194/acp-16-7043-2016, 2016 b.

Groß, S., Esselborn, M., Weinzierl, B., Wirth, M., Fix, A., and Petzold, A.: Aerosol classification by airborne high spectral resolution lidar observations, Atmos. Chem. Phys., 13, 2487-2505, https://doi.org/10.5194/acp-13-2487-2013, 2013.

Haustein, K., Pérez, C., Baldasano, J. M., Müller, D., Tesche, M., Schladitz, A., Esselborn, M., Weinzierl, B., Kandler, K., and von Hoyningen-Huene, W.: Regional dust model performance during SAMUM 2006, Geophys. Res. Lett., 36, 103812, https://doi.org/10.1029/2008GL036463, 2009. 
Hess, M., Koepke, P., and Schult, I.: Optical Properties of Aerosols and Clouds: The Software Package OPAC, B. Am. Meteorol. Soc., 79, 831-844, https://doi.org/10.1175/15200477(1998)079<0831:OPOAAC >2.0.CO;2, 1998.

Hodzic, A., Chepfer, H., Vautard, R., Chazette, P., Beekmann, M., Bessagnet, B., Chatenet, B., Cuesta, J., Drobinski, P., Goloub, P., Haeffelin, M., and Morille, Y.: Comparison of aerosol chemistry transport model simulations with lidar and Sun photometer observations at a site near Paris, J. Geophys. Res.-Atmos., 109, d23201, https://doi.org/10.1029/2004JD004735, 2004.

Holben, B., Eck, T., Slutsker, I., Tanré, D., Buis, J., Setzer, A., Vermote, E., Reagan, J., Kaufman, Y., Nakajima, T., Lavenu, F., Jankowiak, I., and Smirnov, A.: AERONET - A Federated Instrument Network and Data Archive for Aerosol Characterization, Remote Sensi. Environ., 66, 1-16, https://doi.org/10.1016/S0034-4257(98)00031-5, 1998.

Huneeus, N., Schulz, M., Balkanski, Y., Griesfeller, J., Prospero, J., Kinne, S., Bauer, S., Boucher, O., Chin, M., Dentener, F., Diehl, T., Easter, R., Fillmore, D., Ghan, S., Ginoux, P., Grini, A., Horowitz, L., Koch, D., Krol, M. C., Landing, W., Liu, X., Mahowald, N., Miller, R., Morcrette, J.-J., Myhre, G., Penner, J., Perlwitz, J., Stier, P., Takemura, T., and Zender, C. S.: Global dust model intercomparison in AeroCom phase I, Atmos. Chem. Phys., 11, 7781-7816, https://doi.org/10.5194/acp11-7781-2011, 2011.

Jiménez-Guerrero, P., Pérez, C., Jorba, O., and Baldasano, J. M.: Contribution of Saharan dust in an integrated air quality system and its on-line assessment, Geophys. Res. Lett., 35, 103814, https://doi.org/10.1029/2007GL031580, 2008.

Katragkou, E., Zanis, P., Tegoulias, I., Melas, D., Kioutsioukis, I., Krüger, B. C., Huszar, P., Halenka, T., and Rauscher, S.: Decadal regional air quality simulations over Europe in present climate: near surface ozone sensitivity to external meteorological forcing, Atmos. Chem. Phys., 10, 11805-11821, https://doi.org/10.5194/acp-10-11805-2010, 2010.

Kokkalis, P., Papayannis, A., Amiridis, V., Mamouri, R. E., Veselovskii, I., Kolgotin, A., Tsaknakis, G., Kristiansen, N. I., Stohl, A., and Mona, L.: Optical, microphysical, mass and geometrical properties of aged volcanic particles observed over Athens, Greece, during the Eyjafjallajökull eruption in April 2010 through synergy of Raman lidar and sunphotometer measurements, Atmos. Chem. Phys., 13, 9303-9320, https://doi.org/10.5194/acp-13-9303-2013, 2013.

Kokkalis, P., Amiridis, V., Allan, J. D., Papayannis, A., Solomos, S., Binietoglou, I., Bougiatioti, A., Tsekeri, A., Nenes, A., Rosenberg, P. D., Marenco, F., Marinou, E., Vasilescu, J., Nicolae, D., Coe, H., Bacak, A., and Chaikovsky, A.: Validation of \{LIRIC $\}$ aerosol concentration retrievals using airborne measurements during a biomass burning episode over Athens, Atmos. Res., 183, 255-267, https://doi.org/10.1016/j.atmosres.2016.09.007, 2017.

Kuenen, J., van der Gon, H., Visschedijk, A., Dröge, R., and van Gijlswijk, R.: MACC European emission inventory for the years 2003-2007, Tech. Rep. TNO-060-UT-2011-00588, The Netherlands Organisation report, 2011.

Lopatin, A., Dubovik, O., Chaikovsky, A., Goloub, P., Lapyonok, T., Tanré, D., and Litvinov, P.: Enhancement of aerosol characterization using synergy of lidar and sun-photometer coincident observations: the GARRLiC algorithm, Atmos. Meas. Tech., 6, 2065-2088, https://doi.org/10.5194/amt-6-2065-2013, 2013.
Mamouri, R. E. and Ansmann, A.: Fine and coarse dust separation with polarization lidar, Atmos. Meas. Tech., 7, 3717-3735, https://doi.org/10.5194/amt-7-3717-2014, 2014.

Marécal, V., Peuch, V.-H., Andersson, C., Andersson, S., Arteta, J., Beekmann, M., Benedictow, A., Bergström, R., Bessagnet, B., Cansado, A., Chéroux, F., Colette, A., Coman, A., Curier, R. L., Denier van der Gon, H. A. C., Drouin, A., Elbern, H., Emili, E., Engelen, R. J., Eskes, H. J., Foret, G., Friese, E., Gauss, M., Giannaros, C., Guth, J., Joly, M., Jaumouillé, E., Josse, B., Kadygrov, N., Kaiser, J. W., Krajsek, K., Kuenen, J., Kumar, U., Liora, N., Lopez, E., Malherbe, L., Martinez, I., Melas, D., Meleux, F., Menut, L., Moinat, P., Morales, T., Parmentier, J., Piacentini, A., Plu, M., Poupkou, A., Queguiner, S., Robertson, L., Rouïl, L., Schaap, M., Segers, A., Sofiev, M., Tarasson, L., Thomas, M., Timmermans, R., Valdebenito, Á., van Velthoven, P., van Versendaal, R., Vira, J., and Ung, A.: A regional air quality forecasting system over Europe: the MACC-II daily ensemble production, Geosci. Model Dev., 8, 2777-2813, https://doi.org/10.5194/gmd-8-2777-2015, 2015.

Markakis, K.: Contribution to the study of particle pollution in Greece, PhD thesis, Laboratory of Atmospheric Physics, Aristotle University of Thessaloniki, 2010.

Markakis, K., Giannaros, T., Poupkou, A., Liora, N., Melas, D., Sofiev, M., and Soares, J.: Evaluating the impact of particle emissions from natural sources in the Balkan region, in: European Aerosol Conference 2009, 6-9 September 2009, Karlsruhe, Germany, 2009.

Markakis, K., Katragkou, E., Poupkou, A., and Melas, D.: MOSESS: A New Emission Model for the Compilation of Model-Ready Emission Inventories-Application in a Coal Mining Area in Northern Greece, Environ. Model. Assess., 18, 509$521,2013$.

Meier, J., Tegen, I., Mattis, I., Wolke, R., Arboledas, L. A., Apituley, A., Balis, D., Barnaba, F., Chaikovsky, A., Sicard, M., Pappalardo, G., Pietruczuk, A., Stoyanov, D., Ravetta, F., and Rizi, V.: A regional model of European aerosol transport: Evaluation with sun photometer, lidar and air quality data, Atmos. Environ., 47, 519-532, https://doi.org/10.1016/j.atmosenv.2011.09.029, 2012.

Menut, L., Flamant, C., Pelon, J., and Flamant, P. H.: Urban boundary-layer height determination from lidar measurements over the Paris area, Appl. Optics, 38, 945-954, https://doi.org/10.1364/AO.38.000945, 1999.

Mona, L., Liu, Z., Mueller, D., Omar, A., Papayannis, A., Pappalardo, G., Sugimoto, N., and Vaughan, M.: Lidar measurements for desert dust characterization: an overview, Adv. Meteorol., 2012, 1-36, https://doi.org/10.1155/2012/356265, 2012.

Mona, L., Papagiannopoulos, N., Basart, S., Baldasano, J., Binietoglou, I., Cornacchia, C., and Pappalardo, G.: EARLINET dust observations vs. BSC-DREAM8b modeled profiles: 12year-long systematic comparison at Potenza, Italy, Atmos. Chem. Phys., 14, 8781-8793, https://doi.org/10.5194/acp-148781-2014, 2014.

Morcrette, J., Boucher, O., Jones, L., Salmond, D., Bechtold, P., Beljaars, A., Benedetti, A., Bonet, A., Kaiser, J. W., Razinger, M., Schulz, M., Serrar, S., Simmons, A. J., Sofiev, M., Suttie, M., Tompkins, A. M., and Untch, A.: Aerosol analysis and forecast in the european centre for medium-range weather forecasts 
integrated forecast system: Forward modeling, J. Geophys. Res.Atmos., 114, https://doi.org/10.1029/2008JD011235, 2009.

Nenes, A., Pandis, S. N., and Pilinis, C.: ISORROPIA: A new thermodynamic equilibrium model for multiphase multicomponent inorganic aerosols, Aquat. Geochem., 4, 123-152, 1998.

Nickovic, S., Kallos, G., Papadopoulos, A., and Kakaliagou, O.: A model for prediction of desert dust cycle in the atmosphere, J. Geophys. Res.-Atmos., 106, 18113-18129, 2001.

Nickovic, S., Vukovic, A., Vujadinovic, M., Djurdjevic, V., and Pejanovic, G.: Technical Note: High-resolution mineralogical database of dust-productive soils for atmospheric dust modeling, Atmos. Chem. Phys., 12, 845-855, https://doi.org/10.5194/acp12-845-2012, 2012.

Pappalardo, G., Amodeo, A., Apituley, A., Comeron, A., Freudenthaler, V., Linné, H., Ansmann, A., Bösenberg, J., D’Amico, G., Mattis, I., Mona, L., Wandinger, U., Amiridis, V., AladosArboledas, L., Nicolae, D., and Wiegner, M.: EARLINET: towards an advanced sustainable European aerosol lidar network, Atmos. Meas. Tech., 7, 2389-2409, https://doi.org/10.5194/amt7-2389-2014, 2014.

Pay, M., Piot, M., Jorba, O., Gassó, S., Gonçalves, M., Basart, S., Dabdub, D., Jiménez-Guerrero, P., and Baldasano, J.: A full year evaluation of the CALIOPE-EU air quality modeling system over Europe for 2004, Atmos. Environ., 44, 3322-3342, https://doi.org/10.1016/j.atmosenv.2010.05.040, 2010.

Pay, M. T., Jiménez-Guerrero, P., Jorba, O., Basart, S., Querol, X., Pandolfi, M., and Baldasano, J. M.: Spatio-temporal variability of concentrations and speciation of particulate matter across Spain in the CALIOPE modeling system, Atmos. Environ., 46, 376396, https://doi.org/10.1016/j.atmosenv.2011.09.049, 2012.

Pérez, C., Nickovic, S., Baldasano, J. M., Sicard, M., Rocadenbosch, F., and Cachorro, V. E.: A long Saharan dust event over the western Mediterranean: Lidar, Sun photometer observations, and regional dust modeling, J. Geophys. Res.-Atmos., 111, d15214, https://doi.org/10.1029/2005JD006579, 2006a.

Pérez, C., Nickovic, S., Pejanovic, G., Baldasano, J. M., and Özsoy, E.: Interactive dust-radiation modeling: A step to improve weather forecasts, J. Geophys. Res.-Atmos., 111, d16206, https://doi.org/10.1029/2005JD006717, 2006b.

Poupkou, A., Giannaros, T., Markakis, K., Kioutsioukis, I., Curci, G., Melas, D., and Zerefos, C.: A model for European Biogenic Volatile Organic Compound emissions: Software development and first validation, Environ. Modell Softw., 25, 18451856, 2010.

Raut, J.-C. and Chazette, P.: Assessment of vertically-resolved $\mathrm{PM}_{10}$ from mobile lidar observations, Atmos. Chem. Phys., 9, 8617-8638, https://doi.org/10.5194/acp-9-8617-2009, 2009.

Royer, P., Chazette, P., Sartelet, K., Zhang, Q. J., Beekmann, M., and Raut, J.-C.: Comparison of lidar-derived $\mathrm{PM}_{10}$ with regional modeling and ground-based observations in the frame of MEGAPOLI experiment, Atmos. Chem. Phys., 11, 1070510726, https://doi.org/10.5194/acp-11-10705-2011, 2011.

Schneider, J., Balis, D., Böckmann, C., Bösenberg, J., Calpini, B., Chaikovsky, A., Comeron, A., Flamant, P., Freudenthaler, V., Hågård, A., Mattis, I., Mitev, V., Papayannis, A., Pappalardo, G., Pelon, J., Perrone, M., Resendes, D., Spinelli, N., Trickl, T., Vaughan, G., and Visconti, G.: European aerosol research lidar network to establish an aerosol climatology (EARLINET), J. Aerosol Sci., 31, S592-S593, 2000.
Schumann, U., Weinzierl, B., Reitebuch, O., Schlager, H., Minikin, A., Forster, C., Baumann, R., Sailer, T., Graf, K., Mannstein, H., Voigt, C., Rahm, S., Simmet, R., Scheibe, M., Lichtenstern, M., Stock, P., Rüba, H., Schäuble, D., Tafferner, A., Rautenhaus, M., Gerz, T., Ziereis, H., Krautstrunk, M., Mallaun, C., Gayet, J.F., Lieke, K., Kandler, K., Ebert, M., Weinbruch, S., Stohl, A., Gasteiger, J., Groß, S., Freudenthaler, V., Wiegner, M., Ansmann, A., Tesche, M., Olafsson, H., and Sturm, K.: Airborne observations of the Eyjafjalla volcano ash cloud over Europe during air space closure in April and May 2010, Atmos. Chem. Phys., 11, 2245-2279, https://doi.org/10.5194/acp-11-2245-2011, 2011.

Shettle, E. P. and Fenn, R. W.: Models for the aerosols of the lower atmosphere and the effects of humidity variations on their optical properties, Tech. rep., 1979.

Skamarock, W. C., Klemp, J. B., Dudhia, J., Gill, D. O., Barker, M., Duda, K. G., Huang, X. Y., Wang, W., and Powers, J. G.: A description of the Advanced Research WRF Version 3, Tech. rep., National Center for Atmospheric Research, 2008.

Stein, O., Flemming, J., Inness, A., Kaiser, J. W., and Schultz, M. G.: Global reactive gases forecasts and reanalysis in the MACC project, Journal of Integrative Environmental Sciences, 9, 57-70, 2012.

Stier, P., Feichter, J., Kinne, S., Kloster, S., Vignati, E., Wilson, J., Ganzeveld, L., Tegen, I., Werner, M., Balkanski, Y., Schulz, M., Boucher, O., Minikin, A., and Petzold, A.: The aerosol-climate model ECHAM5-HAM, Atmos. Chem. Phys., 5, 1125-1156, https://doi.org/10.5194/acp-5-1125-2005, 2005.

Strader, R., Lurmann, F., and Pandis, S. N.: Evaluation of secondary organic aerosol formation in winter, Atmos. Environ., 33, 48494863, 1999.

Takemura, T., Nakajima, T., Dubovik, O., Holben, B. N., and Kinne, S.: Single-Scattering Albedo and Radiative Forcing of Various Aerosol Species with a Global Three-Dimensional Model, J. Climate, 15, 333-352, https://doi.org/10.1175/15200442(2002)015<0333:SSAARF>2.0.CO;2, 2002.

Tesche, M., Ansmann, A., Müller, D., Althausen, D., Engelmann, R., Freudenthaler, V., and Groß, S.: Vertically resolved separation of dust and smoke over Cape Verde using multiwavelength Raman and polarization lidars during Saharan Mineral Dust Experiment 2008, J. Geophys. Res.-Atmos., 114, d13202, https://doi.org/10.1029/2009JD011862, 2009.

Todd, M. C., Bou Karam, D., Cavazos, C., Bouet, C., Heinold, B., Baldasano, J. M., Cautenet, G., Koren, I., Perez, C., Solmon, F., Tegen, I., Tulet, P., Washington, R., and Zakey, A.: Quantifying uncertainty in estimates of mineral dust flux: An intercomparison of model performance over the Bodélé Depression, northern Chad, J. Geophys. Res.-Atmos., 113, d24107, https://doi.org/10.1029/2008JD010476, 2008.

Tomasi, F. D. and Perrone, M. R.: PBL and dust layer seasonal evolution by lidar and radiosounding measurements over a peninsular site, Atmos. Res., 80, 86-103, https://doi.org/10.1016/j.atmosres.2005.06.010, 2006.

Veselovskii, I., Kolgotin, A., Griaznov, V., Müller, D., Wandinger, U., and Whiteman, D. N.: Inversion with regularization for the retrieval of tropospheric aerosol parameters from multiwavelength lidar sounding, Appl. Optics, 41, 3685-3699, https://doi.org/10.1364/AO.41.003685, 2002.

Wagner, J., Ansmann, A., Wandinger, U., Seifert, P., Schwarz, A., Tesche, M., Chaikovsky, A., and Dubovik, O.: Evaluation of the 
Lidar/Radiometer Inversion Code (LIRIC) to determine microphysical properties of volcanic and desert dust, Atmos. Meas. Tech., 6, 1707-1724, https://doi.org/10.5194/amt-6-1707-2013, 2013.

Wandinger, U. and Ansmann, A.: Experimental determination of the lidar overlap profile with Raman lidar, Appl. Optics, 41, 511514, https://doi.org/10.1364/AO.41.000511, 2002.
Zyryanov, D., Foret, G., Eremenko, M., Beekmann, M., Cammas, J.-P., D'Isidoro, M., Elbern, H., Flemming, J., Friese, E., Kioutsioutkis, I., Maurizi, A., Melas, D., Meleux, F., Menut, L., Moinat, P., Peuch, V.-H., Poupkou, A., Razinger, M., Schultz, M., Stein, O., Suttie, A. M., Valdebenito, A., Zerefos, C., Dufour, G., Bergametti, G., and Flaud, J.-M.: 3-D evaluation of tropospheric ozone simulations by an ensemble of regional Chemistry Transport Model, Atmos. Chem. Phys., 12, 3219-3240, https://doi.org/10.5194/acp-12-3219-2012, 2012. 